\title{
NOTAS PARA O ESTUDO DAS RELAÇÕES DOS BANQUEIROS ALEMÃES COM O EMPREENDIMENTO COLONIAL DOS PAÍSES IBÉRICOS NA AMÉRICA NO SÉCULO XVI
}

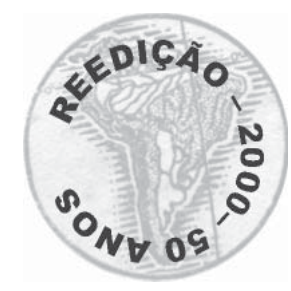

\author{
Maria Thereza Schorer Petrone
}

Res U M 0

O artigo descreve a importante, mas pouco conhecida, participação dos principais banqueiros alemães nos empreendimentos coloniais dos países ibéricos, na América no século XVI, e a tentativa, afinal fracassada, da casa bancária dos Welser de fundar uma colônia na Venezuela

\section{A bstract}

This article describes the important but very little known participation of the main German bankers in Iberian colonial enterprises in Latin America during the XVIth century. The attempt of the Welser bankers in founding a colony in Venezuela is stressed.

\section{Palavias - Chave}

Banqueiros alemães - América ibérica-Comércio colonial-Século XVI

Keywords

German bankers - Iberian America - Colonial trade - XVIth Century

\footnotetext{
* Este artigo foi publicado originariamente na Revista de História $\mathrm{n}^{\mathbf{0}} 32$, 1957, com o seguinte nome e qualificação da autora: Maria Thereza Schorer, Auxiliar de Ensino da Cadeira de História da Civilização Brasileira da FFCL/USP. O texto foi modernizado em sua ortografia e sua Bibliografia padronizada de acordo com as Normas da Revista.
} 
No o fim do século XV e no começo do século seguinte a Europa passou por incisivas transformações que há muito vinham se manifestando. Os ideais do Renascimento, os problemas religiosos, as novas teorias econômicas abalaram a consciência do homem ainda quase completamente preso aos ideais medievais. As forças econômicas começaram a agir mais profundamente na Europa, modificando-a, fazendo surgir nela as características da economia moderna. Os povos descobridores, os banqueiros italianos e alemães contribuíram em grande parte para essas transformações. É interessante que os historiadores, estudando esse período, sempre se preocuparam vivamente com os grandes descobrimentos e com as cidades italianas e seus famosos banqueiros. Apesar de haver excelentes estudos sobre os banqueiros alemães do século XVI, percebe-se, entretanto, que os historiadores raramente se preocuparam em estudar, por exemplo, os banqueiros do sul da Alemanha para caracterizar esse período. A biografia de um banqueiro alemão poucas vezes foi aproveitada para exemplificar a vida e o ideal do homem do Renascimento. Mesmo grandes historiadores de língua alemã como Jakob Burckhardt e Leopold von Ranke não tomaram, por exemplo, os Fugger ou os Welser como símbolos de uma época. O fato de na época de seu apogeu, a fortuna dos Fugger ter sido cinco vezes maior que a dos Médici, passou quase completamente desapercebido! (Hering 1944: 29). Os banqueiros italianos foram eclipsados durante mais de meio século pelo brilho das grandes casas bancárias do sul da Alemanha. Só depois da decadência das mesmas, os genoveses conseguiram reafirmar-se no mundo econômico.

Esse período, devido ao desenvolvimento histórico, teve grande necessidade de capitais para os mais diversos fins. O desenvolvimento do grande comércio e da indústria e o aparecimento de Estados modernos foram responsáveis pela formação do "capitalismo incipiente", como Strieder (1932: 3-26) denomina as manifestações econômicas do fim do século XV e do começo do XVI. Naturalmente o afluxo de metais preciosos das novas terras descobertas, não deixou de influir poderosamente nas transformações econômicas pelas quais a Europa estava passando. E por sua vez, foi o desenvolvimento do "capitalismo" que permitiu o progresso nesses diferentes setores. Os maiores historiadores preocuparam-se com a origem desses capi- 
tais, havendo as opiniões as mais contraditórias. Aprofundar-nos nessa questão levarnos-ia demasiadamente longe; por isso apenas citaremos rapidamente a opinião de Sombart, que acha que os capitais provinham da aplicação das riquezas feudais, e a de Strieder que, apesar de ter sido discípulo de Sombart, procura demonstrar que os grandes capitais surgiram graças ao comércio internacional, tendo os grandes comerciantes quase sempre saído do artesanato e do pequeno comércio local (Sombart 1928 e Strieder 1935).

Strieder (1932: 9), em seu capítulo sobre o advento do capitalismo, afirma que “a história do desenvolvimento do espírito capitalista na Europa é a história do desenvolvimento do indivíduo...”. Mais que na ambição e na cobiça, havia um forte impulso criador, uma força que impelia para a atividade. $\mathrm{O}$ amor à vida de aquém túmulo levava a personalidade criativa a uma participação intensiva na vida, principalmente na econômica ${ }^{1}$.

Nessa época, é claro, houve um grande progresso nas técnicas do capitalismo. Os bancos se desenvolveram. Os créditos, os juros, as letras de câmbio, os sistemas monetários, as bolsas, as especulações, os seguros, as sociedades por ações, tudo vai surgindo e se desenvolvendo, transformando o velho quadro econômico da Idade Média. Não se deve igualmente esquecer as célebres agências de notícias que espalhavam por toda a Europa as últimas novidades. Em Augsburgo eram célebres os novellanten da agência de Schiffle e Crasser (Klarwill 1923: xvii).

As cidades do sul da Alemanha começaram a se destacar economicamente, sobrepujando as de áreas antigamente mais ricas e poderosas como, por exemplo, as cidades da Hansa. Entre as cidades que maior importância adquiriram destacase Augsburgo, velha cidade imperial, pátria de verdadeiras dinastias de banqueiros e comerciantes. Augusta Vindilicorum na célebre via Cláudia foi desde a época dos

\footnotetext{
${ }^{1}$ Poelnitz (1949), em seu magnífico livro Jakob Fugger Kaiser, Kirche und Kapital in der oberdeutschen Renaissance, tece um verdadeiro hino de louvor ao impulso criador e à vontade inquebrantável desse grande banqueiro, típico representante de uma época.
} 
romanos, um centro importante devido ao cruzamento de diversas rotas. Economicamente, Augsburgo era sobrepujada na alta Idade Média por outras cidades do sul da Alemanha, como Nuremberg e Viena. Mas quando Veneza obteve definitivamente a primazia sobre as outras cidades italianas, Augsburgo tornou-se a mais importante transformando-se em entreposto redistribuidor dos produtos venezianos (Hering 1944: 19-20).

Esse comércio de importação e de redistribuição foi em grande parte responsável pelo aparecimento de verdadeiras dinastias de banqueiros e de comerciantes no sul da Alemanha e de suas grandes fortunas. Típico é o caso dos Fugger. Hans Fugger abandonou em 1367 sua pequena aldeia natal no Lechfeld para radicar-se em Augsburgo como tecelão e tintureiro. Pouco a pouco enriqueceu e seus descendentes, ao lado da tecelagem, dedicaram-se também ao comércio. Um século após a mudança de Hans Fugger para Augsburgo, nasceu Jakob Fugger, “o rico”, genial representante do homem de negócios do Renascimento, trabalhador incansável que levou o nome dos Fugger à mais alta glória. Ditou as diretrizes da economia européia. Dirigiu a política e imiscuiuse nos negócios eclesiásticos. Os Fugger já não são mais os simples tecelões de fustão e pequenos comerciantes. A maior parte do comércio internacional esteve nas mãos de Jakob Fugger, "o rico"; possuía monopólios, grandes organizações industriais, destacando-se pelas proporções a mineração no Tirol, na Hungria e na Espanha. Anton Fugger continuou o caminho traçado por seu tio Jakob Fugger, mas logo a decadência se fez notar. Os sucessores de Anton Fugger se preocuparam mais com a obtenção de títulos nobiliárquicos do que com os negócios. A partir da segunda metade do século XVI, os Fugger não têm mais importância na agitada vida econômica da Europa.

Ao contrário dos Fugger, a árvore genealógica dos Welser pode ser seguida até a época de Carlos Magno que, segundo a tradição, deu um brasão a um Welser. $\mathrm{Na}$ época de Conrado II, um Welser, conselheiro imperial, fixou-se em Augsburgo. No fim do século XV a família dividiu-se em dois ramos, pois um Welser transferiu-se para Nuremberg. Ambos os ramos da família se dedicaram intensamente ao comércio e aos negócios financeiros. Bartolomeu Welser foi, sem dúvida, o mais importante. Interessou-se principalmente pelo comércio colonial, estabelecendo diversas feitorias no Novo Mundo. Tentou a colonização da Venezuela. Infelizmente quase não 
há estudos aprofundados sobre essa interessante personalidade. O que será que ele pensava sobre problemas coloniais? A riqueza e o poder dessa casa também não perduraram e, em 1617, os Welser de Augsburgo foram à bancarrota, sendo que um dos membros da família teve que passar sete anos na prisão. Ambas as famílias, os Fugger e os Welser, praticamente desde meados do sécu1o XVI não apresentaram mais personalidades marcantes no mundo econômico. A partir dessa data na crônica das duas famílias só se fazem representar sábios, mecenas e amantes da arte.

Os Fugger e os Welser foram, sem dúvida, as casas bancárias mais importantes do sul da Alemanha. Seus métodos, entretanto, não foram os mesmos. Os Fugger preocuparam-se sempre em participar de negócios estáveis, os Welser não raro se deixaram levar por empreendimentos aventureiros, haja vista a colonização da Venezuela. Só os membros da família podiam ser sócios na firma comercial dos Fugger. Além disso, na época do apogeu fixou-se a norma da direção única ${ }^{2}$. Os Welser nunca tiveram essas diretrizes e, apesar de não constituir costume generalizado na Alemanha do século XVI, os Welser já em 1508 tinham em sua firma acionistas de 12 famílias diferentes (Ehrenberg 1905: 27).

Muitas outras firmas comerciais estabelecidas no sul da Alemanha tiveram uma importância considerável e influíram poderosamente na vida econômica sem, no entanto, poderem ser comparadas aos Fugger e Welser. Destacaram-se principalmente os Hochstetter, os Manlich, os Imhof, os Herwart, os Baumgartner etc.

Todos esses banqueiros e comerciantes, especialmente os Fugger e os Welser, contribuíram sobremaneira para implantar e fortalecer um vasto sistema de crédito em toda a Europa. Foram os financiadores dos papas, dos cardeais, dos grandes e pequenos senhores eclesiásticos, dos imperadores, dos reis e dos príncipes. Todos nesse Zeitalter der Fugger, como Ehrenberg (1896) chama esse período, recorreram

\footnotetext{
${ }^{2}$ Jakob Fugger em seu testamento fixou que Anton Fugger, seu sobrinho, deveria dirigir a sociedade "conforme seu gosto e modo de pensar, como eu em minha vida tive força e poder para agir sozinho” (Ehrenberg 1905: 29). Já se prenuncia, como é sabido, tanto na organização dos Welser como na dos Fugger, o truste.
} 
aos banqueiros alemães para satisfazerem suas necessidades financeiras. Os banqueiros alemães passaram do âmbito estritamente urbano para o nacional, conquistaram depois a Europa, alcançando finalmente com seus tentáculos o mundo inteiro. E isso em menos de um século. Sua ligação com a cúria romana e com a casa imperial fez com que tivessem interesses econômicos em toda a Europa: da Sicília até a Escandinávia, da Rússia até a Ibéria, substituindo em muitos lugares os banqueiros italianos, inclusive os Médici.

$$
* * *
$$

Desde meados do século XV o eixo econômico da Europa transferiu-se do Mediterrâneo para o Atlântico. As velhas repúblicas italianas inutilmente tentaram reagir tanto contra os portugueses e espanhóis com suas rotas marítimas, como contra o ataque turco. Os comerciantes do sul da Alemanha, redistribuidores dos produtos importados pelos italianos foram duramente atingidos pela decadência do comércio do Mediterrâneo. Os banqueiros alemães imediatamente perceberam que seu campo de ação deveria ser transferido para a península Ibérica ${ }^{3}$. O interesse dos alemães pela Ibéria não deve ser considerado apenas uma consequiência do deslocamento do eixo econômico. Desde a Idade Média encontramos aí comerciantes hanseáticos, os quais de início sobrepujavam os comerciantes do sul da Alemanha.

A Espanha e Portugal, que desde a época dos romanos não mais tiveram um papel de grande relevo no mundo econômico, constituíram nessa época um campo favorável para os comerciantes alemães. Dispondo de grandes capitais, é lá que podiam empregá-los, pois tanto Portugal como a Espanha não tinham os meios necessárias para armar todas as esquadras de que tinham precisão. Recorreram ora aos

\footnotetext{
${ }^{3}$ Poelnitz (1949: 146-149), entretanto, chama atenção sobre as atividades de Jakob Fugger, que percebeu que apesar de tudo, Veneza poderia oferecer ume base estável para o comércio do cobre húngaro e da prata. A feitoria alemã nessa cidade, o Fondaco dei Tedeschi, não decaiu tão depressa como geralmente se supõe. É igualmente errado crer-se que as rotas entre as cidades italianas e as do sul da Alemanha perderam sua importância.
} 
alemães, ora aos italianos, sendo em certos períodos os alemães os mais importantes. O comércio de especiarias, direto ou não, e principalmente o de redistribuição pela Europa, concentrou-se quase totalmente nas mãos dos alemães durante certo tempo. Não se deve esquecer que por um acontecimento de grande repercussão histórica, a Espanha e o Sacro Império estiveram unidos sob uma mesma coroa. Esse fato, em grande parte, foi responsável pela participação sempre crescente dos banqueiros alemães, credores de Carlos V, nas atividades econômicas da Ibéria. Foram naturalmente os Fugger e os Welser que mais se sobressaíram pela intensidade de suas atividades. Devido à participação intensa dos banqueiros na vida econômica da Península, essa transformou-se cedo em trampolim desses alemães para o Novo Mundo.

$* * *$

Desde a alta Idade Média houve relações entre Portugal e alemães, principalmente os do norte ${ }^{4}$. Com a decadência do comércio no Mediterrâneo, os banqueiros do sul da Alemanha com seus grandes capitais substituíram os hanseáticos. As primeiras feitorias desses alemães foram fundadas nos primeiros anos do século XVI, mas é provável que desde a chegada dos primeiros carregamentos de pimenta se tenham interessado mais vivamente. Desde a viagem de Vasco da Gama os Welser, certamente através de seus primeiros estabelecimentos em Espanha, preocuparamse com o comércio das Índias. No começo do ano de 1503 apareceu em Lisboa um agente dos Welser, Simon Seitz, com a finalidade de conseguir de D. Manuel um acordo comercial. Segundo a coletânea de documentos publicada por Cassel, esse

\footnotetext{
${ }^{4}$ Schumacher (1892) fez um estudo sobre os primeiros alemães encontrados em Portugal. É certo que alemães participaram da conquista de Lisboa. Em 1403 chegaram a Lisboa navios de Danzig. Um alemão, Jobst von Hurten chegou a ser stathalter nos Açores em 1486; Panhorst (1928: 16) chega mesmo a afirmar que navios levaram emigrantes alemães do baixo Reno e de Flandres para Portugal, sendo que na época de D. João I houve uma colonização alemã planejada; Cassel (1771) e Denucé (s/d) publicaram como primeiro documento um privilégio concedido em 1452 a habitantes dos Países Baixos, alemães, franceses e ingleses e em especial a um sapateiro alemão Michael Harmen libertando-os de uma série de obrigações, tais como o pagamento de impostos e contribuições, serviços, etc.
} 
acordo foi firmado a 13 de janeiro de 1503, mas os originais portugueses trazem a data de 13 de fevereiro. Esse acordo não pode ser de janeiro, pois Lukas Rem, futuro feitor dos Welser em Lisboa, conta em seu curioso diário que a 12 de dezembro de 1502, ele e Simon Seitz estavam viajando entre Saragoça e Tolosa (Rem [1494-1541] 1861). Conclui-se, portanto, que a data só pode ser 13 de fevereiro e que mesmo assim Seitz agiu muito depressa para conseguir o acordo. Para se ter uma idéia melhor do que foi concedido aos alemães, transcrevemos o acordo na íntegra. Os privilégios eram de tal ordem "que a nenhus outros nem aos nossos suditos ainda forão conçedidos...” como se diz no próprio acordo:

"Dom Manoel por graça de Deos Rey de Portugal, e dos Algarues, daquem e dalem mar em Africa Senhor de guine, e da conquista, nauegação commercio de Ethiopia arabia, persia e da jndia etc. A todos que estas nossas Letras virem muita saude e dezejo de amor por quanto de boa vontade acustumamos a honrrar aos que são dignos de Honrra, e com Liberal benefficio os proseguir, chegando a nos o aprouado varão Simão Seyes com a custumada humanidade o Ouuimos, e liberalmente o despachamos segundo em estas Letras se mostra, elle veyo a nos em nome dos respeitaueis varões Antonio de Belzer, e Conrrado filim em nome seu, e da sua Companhia dos nobres mercadores da Imperial Cidade Augusta, e doutras villas de Alemanha Significando nos que elles querião em esta nossa cidade de Lixboa asentar sua casa de sua companhia pera negocear, e tratar mercadorias em nossos Reinos se a nos approuesse outorgandolhe alguas graças, e Liberdades que nos pedião segundo em outras terras lhe erão dadas, e nos entendendo em seu requerimento, e considerando quanta honrra, e Humanidade a taes varões seia diuida assi pollas suas proprias pessoas dignas de todo fauor como pello seu commedavel trato que segundo nos parece aos nossos aproueitara como também por serem Cidadões imperiais do muito Augusto Maximiliano emperador dos Romanos nosso muito amado sobrinho pollo qual com boa vontade demos consentimento a sua petição outorgandolhe as Liberdades, e priuilegios que pedião os quaes a nenhus outros nem aos nossos subditos ainda forão conçedidos segundo todos em estas Letras Largamente será conteudo.

Item Primeiramente outorgamos aos dítos nobres mercadores que possão Liuremente negocear, e tratar, e comprar, e vender por todos os nossos Reynos, e senhorios por suas pessoas ou por seus feitores, e seruidores, Item queremos que toda a prata [e ouro] que por mar ou terra a nossos Reinos, e senhorios trouxerem não seião obrigados pagar portagem [o documento alemão 
não fala em portagem] nem disima nem outro algum direito ou tributo, e que a tal prata que assi trouxerem possão vender a quem lhe aprouver, e a que não venderem Livremente tornar a Leuar fora de nossos Reinos sem impedimento algum. Item queremos também, e outorgamos aos ditos mercadores, e companhia que das mercadorias a baixo nomeadas que a nossos Reinos, e senhorios trouxerem S. Latão Cobre por Laurar, vermelham, azougue, Mastos de Naos antenas, Pez, Alcatrã [balas], e Pilitaria não paguem elles nem aquelles que dos ditos Mercadores as comprarem outro direito ou tributo senão dez por sento assi pagos possão Leuar, essas mercadorias sem mais paguarem alguma siza ou portagem ou outro algum direito ou tributo, e se por uentura os ditos mercadores não venderem as ditas mercadorias queremos que as possão Liuremente tornar a leuar fora de nossos Reinos e senhorios sem lhe cousa alguma embargar, e porem nas outras mercadorias que afora as em sima declaradas os ditos mercadores trouxerem sera guardado no pagamento do direito ou tributo dellas a Vzo, e costume de nossos Reinos, e senhorios.

Item Nos praz, e conçedemos que se os ditos mercadores comprarem em pequena ou grande quantidade Especiarias ou brasil ou outras quaes quer mercadorias trazidas da India ou de terras [ilhas] nouas proximamente achadas não seião obrigados por tal compra pagar siza nem outro direito ou tributo Leuando as ditas mercadorias fora de nossos Reinos, e Senhorios tirando aquellas mercadorias que comprarem da frota e Naos que o ano passado o nosso Almirante leuou a India nem tambem na tornada das Naos das duas frotas que ora temos prestes pera a India das quaes mercadorias em as ditas Naos quando as comprarem pagarão os ditos mercadores de sisa somente sinquo por sento [devem pagar cinco por cento de aduana], e pello semelhante pagarão outro tanto das mercadorias que comprarem das Naos de fernão de Noronha nosso subdito durando seu contrato que por nos com elle he firmado das terras nouas o qual trato se acabara no anno de quinhentos, e sinquo, e por compra das mercadorias das outras Naos que daqui em diante da India vierem e também das terras nouas depois do tempo do dito fernão de Noronha não pagarão os ditos mercadores cousa algua de direito ou tributo dahy auante.

Item queremos tambem que toda a moeda douro, e prata que aos ditos mercadores sobejar, e remaneçer daquellas que a nossos Reinos e senhorios trouxerem a propria moeda a quizerem Leuar fora de nossos Reinos, e Senhorios que o possão fazer liurementte, e se por uentura algua prata uenderem daquella que a nossos Reinos trouxerem a nos praz que o ouro [dinheiro] que por tal venda receberem possão semelhantemente leuar fora de nossas Reinos, e senhorios posto que seia em moeda deste Reino, "Mesmo já sendo moeda desse Reino" e quando quer 
que as taes moedas quizerem Leuar aueram nossas cartas para os officiaes dos passos, e portos dos nossos Reinos, e senhorios com as quaes Liuremente possão passar com o ouro que consigo Leuarem o qual ouro sera posto em boetas ou borjoletas suas serradas, e uistas primeiro por nosso official que nesta cidade de Lixboa pera ello ordenamos o qual as assinara as fechaduras das boetas ou borjoletas com o sello tambem para ello ordenado de giza que dada assi tal ordem, e modo mediante nossas cartas possam os dittos mercadores Liuremente passar, e sair de nossos Reinos sem mais impedimento algum ou manifestação ou inquirição das pessoas, e couzas suas que se soem de fazer segundo as Leys, e o custume do Reino a qual cousa nos assi pareçeo por bem dos ditos Mercadores para de todo, euitar toda a occaziam de damno que doutra maneira facilmente poderia acõteçer, e assim a cauza delles nos seria muito molesta.

Item Outorgamos aos ditos mercadores que se por ventura em nossos Reinos, e Senhorios fizerem alguas Naos de qual quer grandura que sejão possam com ellas gosar, e gosem dos priuilegios, e Liberdades que tem nossos subditos em todas nossas partes, e costas do mar [em todos os portos e rios] assim esses nauios como as mercadorias que trouxerem não somente aos nossos Reinos, e senhorios mas a quaes quer outros com tanto que pera gosarem dos dittos priuilegios, e Liberdades os dittos seus nauios sejão ministrados, e gouernados por marinheiros, e mestres naturaes de nossos Reinos tirando que esta imunidade não aja Lugar nas nossas Ilhas de madeira como em todalas outras por que lhe são dados taes priuilegios contra que se não pode hir.

Item Nos praz que se os ditos mercadores Edificarem algua caza em qual quer Lugar desta cidade dentro, ou fora dos muros não lhe seja dado varejo em suas mercadorias que tiuerem em sua caza assi por elles edifficada no chão que por elles for comprado pello modo que aos flamengos que vierem a nossos Reinos por nos he outorgado.

Item Conçedemos aos ditos mercadores que sejão Liures e não sejão obrigados a colação ou pagamento de peitas ou pedidos que pellos Reinos ou prouincias se costumão muitas uezes, pedir, e poer.

E se o que Deos tolha entre os nossos Reinos, e as gentes, e terras dos ditos mercadores nasçer guerra ou outro algum Príncipe ou Rey de que se sigua alguma toruação a estada delles em nossos Reinos a nos apraz, e outorgamos que as pessoas dos ditos mercadores, e de seus feitores, e seruidores, e tambem as mercadorias, e todos os seus bens. não reçebão ditrimento algum nem posão. em elles ser feitos embargos nem Reprezarias [prisão, represália ou pena] por nenhum pacto por nos ou por nossos subditos mas em verdade se quisermos, e mandarmos que os ditos mercadores se uão de nossos Reinos, e Senhorios quere- 
mos, e outorgamos lhe de graça special que alem do termo publicamente divulgado tenhão ainda espaço alongado de um inteiro anno e dia para estarem em nossos Reinos em que mais conuenientemente possão suas cousas dispoer, e tirar fora de nossos reinos para onde quizerem.

E tambem Nos praz Conçeder aos ditos mercadores faculdade de escolherem hum so Corretor que segundo parese pode abastar para tratar suas mercadorias porem com tal Limitação que este corretor que assi escolherem seia obrigado nas compras, e uendas das mercadorias ajuntar consigo outros corretores desta cidade, e sobsinar com elles nos seus Liuros, e tambem commonicar com elles o proueito, e ganho de seu officio igualmente.

Item Conçedemos aos ditos mercadores que quando suas mercadorias vierem a nossas Alfandegas seião dizimadas, e despachadas primeiro que todas as outras que ahy estiuerem, e mandamos aos oficciaes dellas que com diligencia o cumprão e não fação o contrario.

E tambem Mandamos aos officiaes da nossa moeda que quando quer que os ditos mercadores lhe derem algua prata pera laurar em moeda que seia primeiro Laurada que qual quer outra que ahy estê.

Item Estes Priuilegios, e immunidades Conçedemos aos ditos mercadores por tempo de quinze annos da Dada destas nossas Letras em diante.

E mais porque o dito Simão Syes não somente procurou estas immunidades, e priuilegios pera a dita sua Companhia mas também pera qual quer outra companhia de Alemães que em a nossa cidade de Lisboa quizer assentar caza pera a dytta nossa negoceação de trato nos apras por estas letras conçeder a qual quer outra companhia de mercadores Alemães estes nossos priuilegios, e immunidades que aqui são conteudos, e tambem singularmente a qual quer Alemão mercador que pera Sy so aqui quizer tratar comtanto que a faculdade de seu trato possa valler somma de dez mil cruzados tirando que na compra das mercadorias das naos [navios que acima foram proibidos] que com o nosso Almirante vão, e tambem daquellas duas frottas que ora estao prestes pera ìrem, e taobem das naos de fernão de Noronha durando o tempo de seu trato das terras nouas assi como asima he declarado, e expresso de que a companhia do dito Simão sies não he obrigado pagar mais que sinquo por sento, os outros mercadores pagem dez por sento de siza mas dias mercadorias que depois vierem em outras naos sejão Liures, e nao sejão obrigados pagar cousa alguma assi como a companhia do dito Simão Syes por benefficio do dito priuilegio, e em fe, e em testemunho deta conçeção, e tambem por segurança dos ditos mercadores mandamos fazer estas Letras por nossa propria mão assinadas, e do nosso çello de chumbo pendente 
selladas. Dada em a Cidade de Lixboa a treze de feuereiro do anno de mil, e quinhentos, e tres. - El Rey"

O mais importante desse privilégio é que se incluiam produtos de países recentemente descobertos e a possibilidade de participar no comércio colonial em determinadas condições. Certamente a boa vontade do rei português está ligada a ótima experiência que teve anteriormente com mercadores alemães e naturalmente a grande necessidade de crédito de D. Manuel. Além disso, é bem conhecida a importância do cobre e da prata para a aquisição das especiarias no Oriente. "A afluência de prata e de cobre abriu para os alemães também em Lisboa as mais sedutoras perspectivas e fêz com que o rei D. Manuel viesse de encontro a seus desejos da maneira a mais solícita" (Haebler 1903: 12).

Não se deve esquecer que muitas das regiões descobertas não estavam abertas inteiramente para os próprios portugueses. É interessante verificar que uma semana depois da concessão dos privilégios a Siman Seitz, o famoso Valentim Fernandes da Boêmia foi nomeado corretor para o comércio de especiarias entre portugueses e estrangeiros:

"Dom Manuell, etc. Aquamtos esta nosa carta virem fazemos saber que, avemdo nos Respeyto ao gramde negocio que com ajuda de noso Senhor esperamos que aja nesta cidade de Lixboa, por causa de muitas mercadorias e mercadores estrangeiros que a ella am de vir, pera nella trautarem e asemtarem casas pera o trauto da especiaria, pera omde nos parece necesario acrecemtarmos mais huum coretor alem dos doze que ora ha na dita cidade; avemdo iso mesmo respeyto a Valemtym Fernandez, escudeiro da casa da Rainha mynha Senhora e Irmaã, ser pesoa que neste negocio por causa de sua linguagem e descryçom nos sabera bem e fiellemente seruir; e como yso mesmo Symam Sayz mercador alemaão, que ora com nosco em nome de sua companhya asemtou e fez concerto pera vir asemtar casa e trautar nesta cidade, nos pedio que o dito Valemtym Fernamdez ouuesemos por tem ser coretor e terceiro amtre elles e nosos naturaes; e por lhe

\footnotetext{
${ }^{5}$ Transcrevemos o documento publicado por J. Denucé no "Archivo Histórico Portuguez", vol. VII. O documento português coincide quase inteiramente com o alemão publicado por Cassel. Colocamos entre colchetes as diferenças mais importantes que o texto alemão apresenta com relação ao português.
} 
fazermos graça e mercee: temos por bem e nos praz lhe fazermos mercee do dito ofício de coretor, que ora asy nouamente acrecemtamos pera serem treze na dita cidade... E queremos, que além do dito Valemtym Fernandez asy ser coretor, elle posa fazer e faça pubrico aquellas scripturas contrautos e quaesquer outras cousas que hos ditos mercadores alemães antre sy huuns com os outros fezerem, e asy treladara seus contratos e obrigaçõoes e quaesquer outras scripturas, que em sua lymgoagem tyuerem e quyserem tirar em latym ou em limgoagem portugues, asynamdoas elle dito Valemtym Fernamdez do seu pubrico synall queremos que valham e sejam asy verdadeiras como se fosem feitas e asynadas por tabeliam pubrico. E esto nom avera lugar nem se emtemdera naquelles comtratos obrigaçõoes que se fizerem antre alemãees e portuguezes, porque estes se faram per os tabelliãees pubricos sugundo nosa ordenamça... E esta merce que asy fazemos he por quamto nós podemos acrecemtar mais coretores, alem dos doze ordenados, crecemdo o trauto e maneo delle, como louuores a noso Senhor crece; quamdo capitolar estes alemãees com nosco da companhia do dito Symom ho outorgamos por ser o dito Valemtym de sua lingoagem e mylhor se emtemder com elles. E elle seuira o dito oficio em quamto a companhia dos ditos alemãees esteuerem nestes Regnos" ${ }^{6}$.

Em maio, Lucas Rem, que permaneceu em Portugal de 1503 até 1508 e a quem devemos um grande número de informações contidas em seu minucioso diário, instalou a primeira feitoria alemã em Lisboa. No outono de 1503 deve ter aparecido em Lisboa um agente dos Fugger, pois a 6 de outubro D. Manuel deu a Ulrich Fugger e a seus irmãos um privilégio que, na realidade, nada mais era que a extensão aos Fugger do privilégio conseguido por Seitz ${ }^{7}$. Haebler afirma que o conteúdo dos diferentes parágrafos coincide quase verbalmente com o primeiro. Conseguiram que a taxa aduaneira fosse abaixada de $10 \%$ para $5 \%$. As restrições continuaram vigorando. Outros alemães, como os Imhof, os Hirschvogel e os Hochstetter devem ter seguido os Fugger imediatamente, pois todos participaram da expedição de 1505. Mas, sem dúvida, foram os Welser que mais se destacaram. Perceberam que italianos tomavam

\footnotetext{
${ }^{6}$ Deslandes (1881, apêndice do vol. II).

${ }^{7}$ Haebler (1903: 14) cita o documento Torre de Tombo chancelaria de D. Manuel, livro 22, fo. 25.
} 
parte em diversas frotas. Assim, o principal trabalho da feitoria de Rem foi conseguir as mesmas vantagens. Por intermédio do humanista Peutinger, os Welser conseguiram cartas de recomendação de Maximiliano I e de Filipe-o-Belo a D. Manuel. Pediram para participar na frota de Lopo Soares em 1504, tendo à sua disposição uma soma de 20.000 ducados em dinheiro e em mercadorias (Haebler 1903: 1516). D. Manuel, entretanto, não acedeu a esse pedido, mas logo, devido à necessidade de capitais, mudou de idéia. Lucas Rem conseguiu um novo acordo a 1 de agosto de 1504. Rem, entretanto, diz pouquíssimo sobre o acordo: "A primeiro de agosto fizemos o tratado com o rei de Portugal para a armação de 3 navios para as Índias. Saíram a 25 de março de 1504" ".

Os comerciantes tinham que fornecer os navios e prover a manutenção da tripulação durante 18 meses. O capitão e a tripulação deviam ser portugueses ou pelo menos da colônia estrangeira de Lisboa; durante a viagem estariam incondicionalmente sob o capitão da frota. Havia restrições para o comércio nos portos da Índia; todos os negócios, sem exceção, estariam sob o controle do feitor real, ele determinaria o preço da mercadoria a ser comprada ou trocada, mas os participantes podiam comprar tanta mercadoria quanta encontrassem e pudessem transportar para Lisboa. Em Lisboa a mercadoria seria depositada na Casa da Índia. Ao rei caberia $1 / 4$ e $1 / 20$, portanto, cerca de $30 \%$ das especiarias. O resto estaria inteiramente livre ${ }^{9}$ As condições, entretanto, sofreram alterações com o passar do tempo. O que é certo, é que em 1505 puderam participar, talvez pela primeira vez, de uma frota para a Índia, a de Francisco de Almeida.

Os historiadores não estão de acordo quanto à participação alemã na expedição de 1505. Alguns autores, entre os quais Schmidt (1927: 104), afirmam que os Welser, associados aos Hochstetter, Hirschvogel e Imhof armaram por conta própria 3 navios. Haebler (1903: 18) acha que talvez apenas um navio era inteiramente alemão. Ao

\footnotetext{
${ }^{8}$ Rem se enganou na data, é 1505 e não 1504.

${ }^{9}$ Haebler (1903: 17) nos dá todas essas intormações tendo feito a reconstrução desses privilégios usando várias fontes.
} 
que parece, nessa viagem um consórcio de alemães e de italianos (entre os quais se destaca Marchione) forneceram os navios que não eram de propriedade real. Nesse consórcio os Welser eram muitos, se não os mais importantes, pois participaram com 20 mil cruzados, o grupo de Marchione (florentinos e genoveses estavam aliados a ele) com 29.400 e os Fugger com apenas 7 mil $^{10}$. Nessa expedição pelo menos um alemão foi a Índia - Baltasar Sprenger ${ }^{11}$. Provavelmente viajou como agente dos Welser ${ }^{12}$. O lucro da expedição foi muito bom. Rem afirma que "o lucro calculado dessa viagem foi de cerca de 150\%" (1861: 9). O humanista Conrad Peutinger, escrevendo ao secretário do imperador, diz:

“e para nós augsburgueses é um grande elogio [sermos] os primeiros alemães que procuram as Índias. E para honrar sua Majestade pus na carta, como ele os envia como como primeiro rei romano, o que nunca antes aconteceu com nenhum rei romano... que o representante do rei de Portugal na Índia, sujeito a Sua Majestade alemã, anuncie aos reis hindus o que se refere a Sua Majestade real [imperial]",

Além de participarem daí em diante no comércio com a Índia, também se interessaram pelas ilhas do Atlântico e pela África ${ }^{14}$. Lucas Rem esteve entre 15031508 na ilha da Madeira, nos Açores, nas ilhas do Cabo Verde e na "Berbéria"; não fala, entretanto, sobre a finalidade dessa viagem. Mais tarde recebeu dos Welser ordem de viajar para Madeira e para Palma. Viajou em 1509 e em Cabo Santo conferenciou com o feitor dos Welser e, como ele diz: "perguntei e fiquei sabendo de

\footnotetext{
${ }^{10}$ Propylaeen Weltgeschichte (1932, vol. 4, 22).

${ }^{11}$ Panhorst (1928: 55), afirma que existe na biblioteca do Ginásio de Zetbst um fragmento de um manuscrito relatando que um alemão participou da viagem de Vasco da Gama em 1502-1503. Deve ser o primeiro alemão a ter ido à Índia, mas não se sabe nada sobre sua identidade.

${ }^{12}$ Outro alemão, Hans Mayr, também fêz parte dessa frota, mas como agente real. Baltazar Sprenger publicou mais tarde um livro muito curioso Meerfahrt para o qual o pintor Hans Burkmaier fêz uma série de xilogravuras.

${ }^{13}$ Apêndice do Diário de Lucas Rem.

${ }^{14}$ Basta citar a descrição da costa da África de Valentim Fernandes da Boêmia. Já em 1486 havia nos Açores um stathalter alemão - Jobst von Hurten, que recebeu como feudo Fayal e Pico.
} 
muita coisa, dei ordens que julgava necessárias". Foi controlar a situação nas Canárias e voltou para Madeira, desembarcando em Funchal.

"Ai encontrei Leo Ravenspurger, Hans Schmid, [e] na casa de nossa sociedade um regime lastimável, uma situação desonesta. Jacomo [Holzbock] e eu sentamo-nos atrás das contas, não tive sossêgo nem paz, nem de dia, nem de noite, fiz o melhor que pude, dei ordens o melhor que pude... Fiz muitos e grandes protestos, requerimentos contra o capitão e contador por causa da grande injustiça que nos fizeram" "15

Voltando a Portugal, empreendeu uma série de processos contra o rei por causa das ilhas. Apesar de não dizer nada de preciso sobre o interesse dos alemães nas ilhas, ficamos sabendo que havia uma feitoria dos Welser na Madeira com funcionários; que esses banqueiros tinham interesses nos Açores, e que os negócios nas Canárias eram regidos através da feitoria de Lisboa e não através da de Sevilha. Qual o produto que os interessou aí? Os Welser, tendo vendido certa quantidade de pimenta ao rei e, como o pagamento demorasse, conseguiram que esse lhes concedesse 12.000 arrobas de açúcar que os cultivadores da ilha da Madeira tinham que fornecer ao rei como imposto durante os anos de 1508-1509. Rem não se refere a isso, mas sua viagem certamente tinha como fito principal o comércio do açúcar. Rem apenas se refere a um processo sôbre o açúcar que moveu contra o rei quando regressou a Portugal ${ }^{16}$. Aliás, também nas Canárias, como veremos mais tarde, os Welser estavam interessados no comércio de açúcar. Tendo se interessado pelo comércio com a Índia, com as ilhas do Atlântico, nunca ter-se-iam preocupado com o Brasil?

A coroa portuguesa cedo restringiu a participação estrangeira no comércio colonial. Devido a isso e devido às contínuas questões judiciárias com a coroa, os alemães preferiram a Espanha ou então o comércio redistribuidor de especiarias. Welser,

\footnotetext{
${ }^{15} \operatorname{Rem}(1861: 9,12,13$ e 14$)$.

16 "Wasen meist mein hendel, rect widern king der armazion d'India librang etlich zucker, un die gehederischen recht von Madera, Ilhas d'Azores...” (Rem 1861: 14).
} 
Fugger, Hochstetter, Behaim, Hirschvogel, Tucher, Imhof compravam a pimenta e as outras especiarias diretamente na Casa da Índia e levavam-nas principalmente para Antuérpia. As firmas de Augsburgo foram se tornando cada vez mais importantes no comércio europeu ${ }^{17}$. A organização do comércio da pimenta e das outras especiarias sofreu várias transformações no correr do século XVI; todas as modificações foram feitas para melhorar a precária situação financeira da coroa portuguesa. Para regulamentar melhor o comércio da pimenta e evitar a queda dos preços, o rei lançou mão dos contratadores para a redistribuição dessa mercadoria na Europa. Haebler, citando documentos existentes na Tôrre do Tombo, afirma que um dos primeiros contratos foi o de 1512 com os Fugger ${ }^{18}$. Esse contrato estipulava que enquanto houvesse um estoque de pimenta pertencente à coroa, os Fugger deveriam retirar da Casa da Índia para reexportar 17/20 da do rei e apenas 3/20 da armazenada pelos particulares. É interessante verificar que de um momento para outro, os Fugger passam para o primeiro plano (tinham se interessado tão pouco pela frota de 1505); só mais tarde os Welser readquiriram sua posição anterior. Haebler supõe que em 1523 os Welser pelo menos conferenciaram com a coroa para obter o contrato. Nas três últimas décadas do século XVI destacaram-se no comércio direto com as Índias o alemão Conrad Rott e o italiano Giovanni Battista Rovelasca. Mas ambos contavam com o apoio dos grandes capitais dos Welser, dos Fugger e de outros (Haebler 1903: 36 e 1897: 227). No caso de Rovelasca em certa ocasião 5/12 do capital era de alemães ${ }^{19}$.

Os alemães, além do interesse pelo comércio em produtos coloniais, ainda mantinham importantes negócios com outras mercadorias. Já Lucas Rem (1861: 395) nos dá informações sobre os produtos com os quais os Welser negociavam e sua relação praticamente é válida até a decadência do comércio alemão em Portugal:

\footnotetext{
${ }^{17}$ As cartas dos Fugger continuamente falam no Faktor de Antuérpia. Trata-se sempre do feitor português com o qual mantém relações intensas.

${ }^{18}$ Haebler (1903: 27-28); Torre do Tombo, cartas missivas, arm. 26, maço 2, no 73.

${ }^{19}$ Encontramos uma série de feitores e agentes alemães na Índia; Klarwill compilou diversos relatos desses feitores em sua coletânea Fugger-Zeitungen.
} 
"No tempo que passei em Portugal, de 8 de maio de 1503 até 27 de setembro de 1508, empreendi muitos e grandes negócios, vendendo cobre, chumbo, cinabre; mercúrio, e outras coisas, principalmente tecidos flamengos. E em três anos vieram para mim dos Países-Baixos, Inglaterra, Bretanha, países do leste [Ostland] muitos navios com trigo para vender... Em Portugal comprei muitas especiarias e fiz grandes negócios com o rei. E comprei óleo, vinho, [...], algodão. Enviei [funcionários] diversas vêzes para Aragão, mandei comprar figos, na Andaluzia outras frutas. De tudo que me aparecia quis experimentar. Mantive um grande e notável comércio".

Mas também as outras casas comerciais alemãs participavam intensamente no comércio português, assim, por exemplo, o comércio de trigo esteve durante certo período em mãos dos Fugger. Os navios de que Portugal necessitava eram adquiridos em Danzig por intermédio dos Fugger. Esses navios iam a Lisboa, carregados de trigo e de madeiras. Em 1551 houve negociações entre a coroa e os Fugger, para que esses fornecessem de Danzig certo número de navios equipados para o comércio de especiarias; em troca, Portugal lhes oferecia a participação no comércio de especiarias (Hering 1944: 325). Os Fugger, entretanto, negaram-se a isso, devido à instabilidade dos negócios com a coroa.

Os banqueiros alemães também foram os financiadores dos reis portugueses. Em 1560 a coroa interrompeu o pagamento da dívida e os credores alemães e italianos foram prejudicados. Apesar de não podermos comparar as atividades dos banqueiros alemães em Portugal com as suas operações na Espanha, percebe-se que os banqueiros de Augsburgo influíram profundamente nos destinos políticos e econômicos de Portugal.

Os banqueiros de Augsburgo começaram a se interessar mais intensamente pela Espanha a partir da eleição de Carlos V para imperador do Sacro Império. O diário de Lucas Rem nos mostra, entretanto, que muito antes, já em 1502, os Welser mantinham um certo comércio com a Espanha. Nosso cronista esteve certo tempo em Saragoça, talvez devido ao mercado de açafrão daquela cidade. No século XV na Espanha os alemães não eram representados principalmente pelos comerciantes hanseáticos como em Portugal mas pela Magna Societas Alamanorum, geralmente 
comerciantes de Ravensburgo, cidade próxima do lago de Constança. Haebler (1903: 2) acha que os Welser penetraram na Espanha através de seus parentes, os Vohlin de Memmingen (outra pequena cidade próxima ao lago de Constança) que seguiram os passos dos de Ravensburgo. Realmente os empreendimentos na Ibéria são da firma Welser-Vohlin.

Carlos V, um Habsburgo, reuniu debaixo de uma só coroa a pátria dos descobridores e a dos banqueiros de Augsburgo. Os Habsburgos, desde Frederico VII estavam ligados aos banqueiros de Augsburgo, principalmente aos Fugger por contínuos créditos. Já em 1517 quando Carlos V foi tomar posse de sua herança espanhola, havia em seu séquito agentes dos Fugger e dos Welser. A atuação dos banqueiros alemães foi muito mais intensa em Espanha que em Portugal, o capital empatado maior, os lucros maiores, os prejuízos, entretanto, levaram muitos comerciantes à ruína completa. Os Habsburgos para conseguirem sempre mais créditos e para amortizarem as dívidas, concediam aos banqueiros uma série de vantagens e imunidades ou lhes ofereciam em caráter de monopólio a exploração de certos recursos naturais. Carlos V, seguindo a tradição, incorreu em vultosas dívidas para conseguir a coroa imperial, pois os votos dos príncipes eleitores eram venais. O sucessor no trono imperial devia ainda pagar as dívidas que Maximiliano I tinha nas firmas de Augsburgo. Assim se essas firmas resolveram auxiliá-lo na obtenção do trono, não foi, pois, por sentimento de patriotismo ou por consciência de nacionalidade que se imiscuíram no assunto.

As despesas da eleição de Carlos V ficaram em 800.000 florins renanos, dos quais os Fugger deram aproximadamente 600.000 florins. Os Welser e alguns genoveses e florentinos forneceram o resto ${ }^{20}$. Uma soma tão elevada era difícil de ser amortizada e o imperador recorreu a uma série de concessões, reafirmando, por exemplo, os privilégios dos Fugger sobre o cobre húngaro; dessa maneira, eles torna-

\footnotetext{
${ }^{20}$ Poelnitz (1949: 435 e 439) e Hering (1944: 191) que cita uma cifra superior a 850.000 florins renanos.
} 
ram-se imprescindíveis na vida econômica da Espanha, que apresentava, como nenhum outro país, um sistema de arrendamento das rendas públicas muito desenvolvido. Carlos V deu-lhes em 1525 por três anos o arrendamento dos maestrazgos das ordens militares de Santiago, Calatrava e Alcântara para amortizar as dívidas e conseguir um novo empréstimo (Hering 1944: 328 e Poelnitz 1949: 549) . Os Fugger com sua ótima administração tiveram grandes lucros. Durante os seis anos seguintes foram os Fugger e os Welser que as arrendaram. Com exceção de 1535-1537, os Fugger foram os arrendatários até o século XVII. Com essa concessão os Fugger ficaram definitivamente ligados não só à coroa imperial mas aos destinos econômicos da Espanha. Mais importante ainda era o fato de que as minas de mercúrio de Almaden ficavam dentro do território das três ordens e o arrendatário das minas tinha automaticamente o monopólio do mercúrio em toda a Espanha. O mercúrio adquiriu uma importância sem precedentes no comércio mundial devido à descoberta da extração da prata por meio da amálgama. Os Fugger exploraram essas minas até o incêndio de 1550. O monopólio real na exploração dessas minas redundou num grande fracasso, de modo que a coroa preferiu conceder as minas novamente aos Fugger, que as dirigiram de 1562 até 1645 , obtendo grandes lucros graças a sua boa administração.

Os Welser, Imhof, Rott, Tucher etc. também tiveram um papel de destaque na vida econômica da Espanha. Carlos V e Filipe II, apesar de donos de vastíssimo império, sempre tinham necessidade de crédito. Recorriam ao arrendamento de rendas públicas, como com os Fugger, ou pediam somas adiantadas sobre carregamento de metais preciosos provenientes da América. É interessante notar que os Welser preferiram os negócios coloniais, enquanto que os Fugger cedo chegaram à conclusão que para reaver as somas empatadas, era melhor explorar a Espanha. Mas já em 1557, Filipe II em Valladolid publicou um decreto consolidando a dívida pública e ofereceu em troca juros do Estado a 5\%. As consequiências dessa consolidação forçada fizeram-se sentir em toda a Espanha. Esta começou a marchar de uma crise financeira para outra, chegando a ter no começo do século XVII um meio circulante de cobre (Ehrenberg 1896: 155 e 260). A partir da primeira bancarrota e principalmente depois de 1571, os Fugger cederam lugar aos genoveses. As outras casas 
bancárias alemãs já a partir de 1550 foram se afastando cada vez mais, deixando não raro aos Fugger a gerência de seus interesses.

Carlos V, mais que os reis portugueses, facilitou a participação dos alemães no comércio ultramarino. Para um quinhentista constituía uma verdade indiscutível a não participação de estrangeiros no comércio e na colonização das terras recémdescobertas. Isso era reservado com exclusividade para os súditos do país descobridor. O último testamento de Isabel-a-Católica mostra muito bem qual o pensamento dominante sobre esse assunto no período dos descobrimentos:

"Por quanto las Islas é Tierra ferme del Mar Oceano, é Islas de Canaria fueren descubiertas é conquistadas á costo de estos mis Reynos, é con los naturales dellos, y por esto es razon que el trato é provecho dellas se aya, é trate, é negocie de estos mis Reynos de Castilla y de Leon, y en ellos, y á ellos venga todo lo que dellas se traxere: por ende ordeno, é mando que assi se cumple assi en las que faste aqui sea descubiertas, como en las que se descubrirán de aqui adelante en otra parte alguna" ${ }^{, 21}$.

O cronista Oviedo y Valdez soube relatar a transformação desse espírito com muita perspicácia:

“...en tanto que la Cathólica Reyna doña Isabel vivió, no se admitian ni dexaban pasar á las Indias sino a los próprios subditos é vasallos de los señorios del patrimonio de la Reyna, com quiera que aquellos fueron los que las Indias descubrieron, é no aragoneses, ni catalones ni valençianos ó vasallos del patrimonio real del Rey Cathólico. Salvo por especial merced, á algun criado é persona conosçida de la casa real se le daba liçencia no seyendo castellano; porque como estas Indias son de la corona é conquista de Castilla, assi queria la serenissima Reyna, que solamente sus vassalos passassen á estas partes é no otros algunos, si no fuesse por les faça muy señalada merçed; é assi se guardó fasta el fin del año de mill é quinientos é quatro que Dios la llevó á su gloria. Mas despues el Rey Catholico, gobernando los reynos de la serenissima Reyna dona Juana, su fija, nuestra Señora dió lençencia a los aragoneses é á todos sus vassallos que passassem á estas partes con ofiçios é como le plugo. Y despues la Cesárea

\footnotetext{
${ }^{21}$ Apud Haring (1947: 123).
} 
Magestad extendió mas la liçencia, e passan agora de todos sus señorios é de todas aquellas partes, é vassalos que estan debaxo de su monarchia".

Há, entretanto, devido à falta de documentação comprovante, muitas dúvidas e mesmo historiadores especializados nesse assunto não chegaram a conclusões definitivas sobre quando, como e por que foi dada a permissão aos estrangeiros, súditos do imperador. A historiografia alemã, que em tantos casos nos oferece obras e conjuntos de idéias de imprescindível valor, infelizmente nunca se preocupou muito com os problemas coloniais. As obras alemãs que estudam a expansão européia do século XVI são poucas, e o problema da participação dos alemães só incidentalmente é tocado.

$\mathrm{O}$ fato é que os alemães, súditos de Carlos V, receberam a permissão de participar nos negócios coloniais de Espanha, apasar de todas as restrições da Espanha. Herrerra (1726: 208 e 295) por duas vezes se refere à concessão desse privilégio aos alemães. Em 1525 o imperador "a los Belçares Alemanes dió facultad para contratar en las Indias, como si fuesen Naturales de estes Reinos”. Na mesma década, um pouco mais adiante:

"Que desde el dia de la data de esta orden, que fue en Granada, á diez i siete de Noviembre de este Ano, [1526] [...] asimismo se dió licencia general, para que todos los Subditos de su Magestad, de los Reinos, i Señorios de sus coronas, i á todos los Subditos del Imperio i asi Ginoveses, como todos los otros, pudieses pasar á las Indias, i estár, i contratar en ellas, segun, i como lo hacian los naturales de la Corona de Castilla, i de Leon".

Se Herrerra estiver certo, os Welser foram os primeiros a receber o privilégio de comércio com as terras recentemente descobertas; depois esse privilégio foi estendido a todos os súditos do impédio. Antunes y Acevedo (1797) acha, entretanto, que não se deve dar crédito a Herrerra, pois não foi descoberto o édito original (apud Haring 1947: 124). A existência desse édito, entretanto, é comprovada além do testemunho de Herrera pelo relato de Hieronimus Koeler ${ }^{22}$. Há dois fatos que indicam

${ }^{22}$ Manuscrito no Germanisches Museum, Nuremberg (apud Haebler 1892: 48) 
que a política de participação de estrangeiros em negócios coloniais já fora usada antes de 1526 por Carlos V. Pelo édito de 10 de dezembro de 1522 os Fugger foram admitidos ao comércio com as Molucas, e em 1525 os Welser organizaram feitorias em Sevilha e em São Domingos. Parece, portanto, que o édito de Granada funcionou apenas como elemento de legalização perante os espanhóis, que certamente combateram com todos os meios as idéias do imperador.

O que levou o imperador Carlos V a permitir a participação de todos os seus súditos no lucrativo comércio colonial? Nenhum autor, com exceção de Haebler, se preocupou em estudar minuciosamente esse complexo problema, devido à quase completa ausência de dados sobre o assunto. Talvez os alemães impressionados com o misterioso esplendor das riquezas encontradas na América tivessem exercido forte pressão sobre Carlos V, seu devedor, para que lhes concedesse o direito de participar. Damaschke (1929: 173) afirma que os Welser ajudaram Carlos V por ocasião da sua eleição em troca da liberdade de comércio com a América. Haring (1947: 126), grande conhecedor dos problemas coloniais de Espanha, só incidentalmente toca no problema que ora nos interessa. Acha que a concessão tanto pode ser a expressão de idéias menos regionalistas e mais amplas do imperador, como também resultante da pressão exercida pelos banqueiros. Outro historiador, Merriman (1940: 370), tem uma interpretação diferente e que não deixa de convencer. Afirma que Carlos V desconfiava da capacidade econômica dos espanhóis e por isso aboliu as restrições que excluíam os não espanhóis do comércio e da colonização da América. Os beneficiados pelo decreto foram os genoveses e os alemães, nos quais Carlos V reconhecia grande capacidade organizadora e administrativa. O imperador, apesar de nunca ter resolvido os problemas internos de seu império, era suficientemente perspicaz e observador para perceber que os espanhóis eram bons conquistadores e que só obteria algum lucro das terras onde não havia tanta abundância de metais preciosos, se fossem colonizadas e bem administradas. Achamos, entretanto, que não se deve explicar a atitude de Carlos V apenas por um fator. Agradecido a seus banqueiros alemães, impulsionado pelos mesmos, conhecendo sua grande capacidade organizadora, esse rei de Espanha e imperador do Sacro Império Romano Germânico, iluminado pelos 
ideais medievais do Imperium, foi obrigado pelas próprias circunstâncias exteriores a abrir a América a todos os seus súditos.

Antes do decreto de 1526, os banqueiros alemães já participavam do comércio ultramarino, ajudando, como aconteceu em Portugal, a organizar as frotas, especialmente as destinadas às Molucas. Em Portugal foram os Welser que mais se destacaram no comércio de especiarias, mas em Espanha foram os Fugger. Após o regresso da frota de Magalhães, quiseram reservar a participação nas frotas exclusivamente a espanhóis, mas parece que devido a insistência de Jakob Fugger, Carlos V resolveu convidá-lo em dezembro de 1522 para tomar parte nas mesmas. Os Fugger deveriam enviar a La Coruña oito navios carregados de cobre, mastros, alcatrão, piche e estopa ${ }^{23}$. Além disso, os Fugger com alguns associados deram 10.000 ducados e receberam o direito de enviar com a frota um feitor; os Welser entraram com 2.000 ducados. Sendo o total dos investimentos de 16.000 ducados, os alemães forneceram 3/4 (Haebler 1897: 49). Nas duas primeiras viagens às Molucas os Fugger enviaram feitores; assim na primeira, chefiada por Loaisa, foi Georg, ou melhor, Hans Wandler, do qual entretanto nunca mais se teve notícias; na viagem de Sebastião Caboto, sobre a qual há poucos documentos, parece que participou como agente dos Fugger J. Prunbecher, que igualmente não voltou. Lazarus Nuernberger e Ambrosius Ehinger também aparecem como participantes ${ }^{24}$. Devido ao fracasso das viagens e devido à questão com Portugal, os Fugger se desinteressaram pelas Molucas, exigindo uma indenização.

Os Welser, ao contrário dos Fugger, mostraram desde o começo uma verdadeira vocação colonial. Em 1509 adquiriram em Las Palmas grandes áreas. Lucas Rem escreveu em seu diário (1861: 12):

\footnotetext{
${ }^{23}$ Poelnitz (1949: 519). Segundo Haebler (1897: 45), Carlos V se dirigiu ao Conselho de Lubeck a 14 de março de 1523 para avisar que ordenara que Jacob Fugger, juntamente com Diego de Haro, levasse 8 navios para La Coruña.

${ }^{24}$ Panhorst (1928: 83). Esse historiador cita o livro Los primeros alemanes en el Rio del Plata (1926) no qual Lehmann-Nitsche conseguiu mostrar que um tal Hans Brunberger viveu em La Plata até 1545. O verdadeiro nome não se conhece, mas talvez seja identico ao Prunbecher que participou na frota de Caboto.
} 
"a 17 de setembro [1509] à noite viajei com um navio castelhano juntamente com Hans Egelhoff, Jakob Holtzbock, Bartolome Kelli e muitos outros trabalhadores, mestres e empregados da dita ilha da Madeira e cheguei no pôrto da ilha de Palma das Canárias a 21 de setembro à noite e fiquei lá. A 25 cedo fomos a cavalo até Tassacorta, a maldita terra que o dito Egelhoff comprou para nossa sociedade. Fiquei lá até 30 de setembro, fiz muita e grande ordem. Mas eu percebi que Deus não quis que se cumprisse, depois de minha partida, o que mandei. Para canalizar a água, cultivar a terra são necessários vários anos que eu não queria passar lá, apressei-me imediatamente, de dia examinava a terra, a gente, o gado e à noite inteira os livros de contas sem descansar. Apressei-me sem medida, para sair das ilhas no inverno. Deixei lá Hans Egelhoff como superior com muitas pessoas".

Apesar de Rem não se referir aos produtos que lá cultivavam, podemos supor que a cana de açúcar fosse muito importante (Strieder 1932: 22).

Parece que esse empreendimento não deu bons resultados; Rem fala em "terra maldita" e Peutinger diz que a plantação foi destruída por um verme. O certo é que venderam a propriedade a comerciantes de Colônia. Um auto do processo entre esses comerciantes nos informa que os Welser venderam a propriedade a Johan Biesen e Jakob Groenenberger, mas infelizmente não se precisa a data dessa transação:

"Assim aconteceu, que a sociedade dos Welser deliberou vender seus bens como moinhos, vinhedos, casas, águas, campos, gado, gente e outras coisas, com seus implementos e pertences, que eles possuiam nas ilhas Canárias, São Miguel, Las Palmas, Tacacort na Espanha, o que o dito Groenenberg, antigo feitor de Biesen ficou sabendo e deu a conhecer ao dito Johan Biesen e com seu consentimento comprou os ditos bens, campos, águas, moinhos e outras coisas da dita sociedade dos Welser para si próprio e para o dito Johan Biesen e assim em nome de ambos e por causa de ambos por onze mil florins de preço" ${ }^{25}$.

\footnotetext{
${ }^{25}$ Koelner Kautleute im 16 Jahrhundert auf den kanarischen Insein. Publicado por Mollwo (1899); trata-se do único documento que se conhece sobre a venda dessa propriedade dos Welser.
} 
Em 1528, quando os Welser conseguiram a concessão da Venezuela também lhes foi dada licença para cortar cem pinheiros do rei nas ilhas de Tenerife (Panhorst 1928: 194). Essa permissão está ligada à concessão de um lugar nas atarazanas da Casa de Contratacion de Sevilha. Isso demonstra que vinte anos após a viagem de Rem, os Welser não se tinham desinteressado por completo das ilhas do Atlântico.

A península Ibérica funcionou como verdadeiro trampolim para as terras descobertas havia pouco. No Oriente houve em diversos pontos feitorias alemãs, mas foi na América que se estabeleceram e criaram, pelo menos durante alguns anos, bases concretas para suas transações comerciais. Mas nem sempre foram simples bases comerciais: houve verdadeiras tentativas de colonização e interessaram-se intensamente por essa tarefa. Isso se verifica nas diferentes cartas de doação que conseguiram de Carlos V. Um exemplo de seu interesse pela empresa seria o modo como foi preparada a concessão da Costa do Chile, como veremos mais tarde. Das primeiras três viagens os Fugger deveriam levar nada menos que 500 colonos ${ }^{26}$. Também na carta de concessão da Venezuela, os itens sobre a maneira pela qual deveria ser colonizada a região demonstram uma intensa expectativa em torno da empresa. Os alemães, principalmente os Welser, receberam ainda concessões sobre o transporte de mineiros alemães e de escravos negros para São Domingos e Venezuela, o que vem provar que antes de mais nada sua intenção era de tirar lucros de uma colonização estável e bem organizada. Naturalmente essas regiões desconhecidas atiçavam a curiosidade e a cobiça, e assim, por exemplo, pouco a pouco a colonização da Venezuela tomou um caráter de exploração geográfica e de aventura.

Se pudessem ter realizado o que as cartas de doação estipulavam, os banqueiros alemães teriam convertido a colonização em um grande empreendimento. Mas todas as tentativas mais cedo ou mais tarde fracassaram. A decadência dos empreendimentos prende-se em grande parte às hostilidades insuperáveis dos espanhóis para

${ }^{26}$ A colonização do Chile, apesar de todas as conversações nunca foi empreendida. 
com toda e qualquer iniciativa estrangeira. Os banqueiros alemães, bons negociantes que eram, não tinham interesse em empreendimentos cujos lucros seriam duvidosos, assim, após um período de entusiasmo, que é o da década que se segue à eleição de Carlos V, abandonaram todas as tentativas. Em 1556 Filipe II proibiu definitivamente a participação de estrangeiros no comércio e na colonização da América. Já nos 10 últimos anos do governo de Carlos $\mathrm{V}$, o qual se dedicava mais aos negócios imperiais, deixando os da Espanha para Filipe II, começou insensivelmente a restrição à participação de estrangeiros, apesar de o imperador pelo menos oficialmente nunca ter abandonado sua política de admissão. Parece que no fim de seu reinado dera instruções secretas à Casa de Contratacion para excluir, dando muitas desculpas, os alemães dos negócios coloniais (Merriman 1940: 435).

O interessante é observar que na América os Welser e os Fugger nunca apareceram como rivais, como aconteceu na Europa. Os Fugger não se preocuparam tanto com os negócios coloniais como os Welser. A tentativa dos Fugger de colonizar a costa do Chile estava intimamente ligada ao comércio de especiarias. Preocuparam-se mais com os negócios financeiros da própria Espanha, mas é certo que participaram do comércio colonial pelo menos com financiamentos. Os Welser, ao contrário, além das tentativas de colonização, quase que dominaram durante alguns anos o comércio colonial e transoceânico. Parnhorst (1928: 133) afirma mesmo que "em tempo extremamente curto conquistaram na América uma posição tão poderosa que muitas das antigas possibilidades européias de lucro deveriam parecer-lhes pequenas".

A penetração dos banqueiros alemães em terras de Espanha na América se deu através de São Domingos. A feitoria de São Domingos e a de Sevilha eram as mais importantes dos Welser. A participação dos Fugger no comércio com as Molucas, em 1522, e a instalação da feitoria dos Welser em São Domingos, em 1525, são os dois primeiros acontecimentos que demonstram a admissão dos alemães na empresa colonial de Espanha. São Domingos foi, segundo tudo indica, o primeiro estabelecimento de alemães na América. As origens dessa feitoria são muito pouco conhecidas. O primeiro feitor do qual se tem notícias seguras é Ambrósio Ehinger, 
pertencente a uma família intimamente ligada aos Welser. Haebler (1903: 51) afirma que em 1526 ainda se encontrava em Sevilha. Até fins de 1528 Ambrósio Ehinger dirigiu a feitoria e parece que foi ótimo feitor, sendo depois designado para governador da Venezuela. Os diversos acordos que os Welser conseguiram em 1528 são em grande parte devidos à atuação de Ambrósio Ehinger. Sebastian Rentz dirigiu em seguida a importante feitoria. Como fizesse negócios particulares, houve um mandato de prisão contra ele por parte dos Welser (22 de junho de 1531). De 1532 em diante foi dirigida primeiro pelo milanês, Pietro Giacomo Gazio e depois por um florentino, Giovanni Luigi Soderini; durante a gerência desse último estiveram na feitoria Johann Binruten de St. Gall e um agente natural de Lindau (Haebler 1903: 108). Panhorst (1928: 148) tem dúvidas se esses dois italianos foram mesmo responsáveis pela feitoria, argumentando que certos espanhóis que trabalhavam na feitoria dão a impressão de terem sido muito mais importantes que simples escrivães. Aliás, os alemães conhecendo muito bem as verdadeiras teorias coloniais dos espanhóis, tiveram sempre o cuidado de terem um certo número de funcionários espanhóis para evitar invejas e inimizades. Em 1530 havia 4 chefes na feitoria de São Domingos e um ajudante para cada um, portanto, lá trabalhavam oito pessoas, dirigindo o extenso comércio dos Welser na América. Não se sabe até quando essa feitoria funcionou, provavelmente até 1540 ou 1542 (Haebler 1903 e Panhorst 1928).

Talvez a feitoria de São Domingos tenha sido a única feitoria alemã na América organizada sobre bases sólidas. Através dela dirigiram durante certo tempo quase todo o comércio na América. A feitoria de São Domingos teve uma série de funções. Parece que funcionou como banco, foi entreposto de comércio; organizou a mineração, o comércio de escravos negros e a caça ao índio e sua escravização também tiveram certa importância.

Como se sabe, os alemães transportavam para a península Ibérica produtos a serem reexportados para as terras recém-descobertas, cedo naturalmente acharam mais interessante participar diretamente do comércio colonial, daí seu interesse por São Domingos. Panhorst (1928: 111) cita documentos do Archivo General de Indias que mostram que já em 1528 navios alemães tocaram em terras americanas. Para 
auxiliá-los foi concedido aos Welser em 1528 um lugar nas atarazamas ou armazéns da Casa de Contratacion em Sevilha, para guardar "las cosas que se oviéren de llevar y cargar para la dicha tierra" [Venezuela], como se lê na carta de doação da Venezuela. Essa concessão é uma prova concludente do grande poderio dessa firma no campo comercial ${ }^{27}$. A feitoria de São Domingos, de onde partiu a expansão dos Welser e de outros alemães na América, tinha uma importância enorme para o abastecimento, não só das áreas onde tinham interesses imediatos, como por exemplo a Venezuela, mas também de áreas nas quais seu único interesse era o comércio. São Domingos importava os produtos do velho mundo e redistribuia-os. As principais mercadorias eram naturalmente alimentos: farinha, carne salgada, óleo e vinagre, além de ferramentas e outros artigos de primeira necessidade. Treze navios partiram da Espanha com mercadorias para o Novo Mundo até 1 de janeiro de 1532 (Panhorst 1928: 159). Este historiador chama a atenção para o fato de que os documentos só se referem a 7 desses navios como tendo ido até São Domingos. Nos relatos raramente se fala na chegada de um navio dos Welser a São Domingos e num processo de 1535 contra os Welser afirma-se que somente 19 navios tocaram São Domingos. Mas os empreendimentos dos Welser em São Domingos, principalmente os relacionados com a mineração e com o tráfico escravagista demonstram que a navegação deve ter sido bem intensa. Além disso, havia mensalmente uma ligação entre São Domingos e Coro, a capital da província da Venezuela dos Welser. Devido às contínuas interferências da Audiência de São Domingos, os Welser conseguiram uma permissão para deixarem partir seus navios diretamente de Coro para Sevilha sem escala obrigatória em São Domingos. Nessa permissão, entretanto, não há referência à permissão de viagem direta a partir da Espanha, mas os Welser interpretaram a concessão de maneira a mais vantajosa para eles (Panhorst 1928: 160). Além do comércio de produtos de primeira necessidade, há ainda notícias sobre o transporte de cavalos para a Flórida e a Venezuela. Segundo tudo indica, estavam intimamente

\footnotetext{
${ }^{27}$ Essa concessão ainda lhes foi renovada a 7 de agosto de 1535 (Haebler1903 e Haring 1947).
} 
ligados ao comércio de cavalos no Mar das Caraibas e no Golfo do México. Na carta de concessão da Venezuela o rei lhes permitiu:

“... que las nuestras islas Española, San Juan e Cuba y Santiago, podais llevar a la dicha tierra [Venezuela] caballos e yeguas o otros ganados que quisierdes y por bien tuvierdes, sin que en elles vos sea puesto embargo ni impedimiento alguno",

Panhorst afirma que documentos falam do monopólio de exportação de cavalos por três anos para algumas colônias da Flórida e da necessidade da permissão da Audiência; nada se sabe, entretanto, sobre os resultados. O comércio de produtos coloniais naturalmente esteve ligado ao tráfico de escravos negros; os navios negreiros certamente não voltavam vazios para o Velho Mundo. Esses navios, ao lado dos que abasteciam os núcleos de colonização, intensificavam o comércio com produtos coloniais. É provável que os Fugger também estivessem ligados ao comércio com São Domingos pois, segundo tudo indica, não só os Welser praticavam o comércio de escravos negros, mas também os Fugger. Panhorst acredita que existiu em São Domingos uma feitoria dos Fugger, pois caso contrário, de onde teriam obtido um conhecimento tão profundo sobre a América, como demonstraram nas negociações sobre a doaçâo da costa do Chile (Panhorst 1928: 262). Levavam para a Europa tudo que a América oferecia, e o açúcar foi uma das mercadorias mais importantes, já que o pau brasil não podia concorrer em qualidade com o do Brasil (Haebler 1892: 49).

Mais importante que o comércio de abastecimento e de mercadorias coloniais, foi, sem dúvida, o tráfico escravagista. A 12 de fevereiro de 1528 Heinrich Ehinger, irmão de Ambrósio, feitor em São Domingos, e Hieronimus Sailer conseguiram em Burgos um contrato com relação ao comércio de escravos (Haebler 1892, Panhorst 1928 e Haring 1947). O interessante é notar que nos documentos alemães a firma aparece sempre como sendo de Bartolomeu Welser, Ulrich Ehinger e outros parentes,

${ }^{28}$ Carta de doação da Venezuela (Panhorst 1928: 194-7). 
mas nos documentos espanhóis desapareceu qualquer referência aos Welser ${ }^{29}$. Todos os contratos de 1528 foram assinados por Heinrich Ehinger e Hieronimus Sailer e se não soubéssemos que são representantes ou, como acontece em alguns casos, sócios dos Welser, poderíamos chegar a conclusões muito erradas. As negociações para o contrato sobre escravos negros foram realizadas por Sailer agindo em nome de Heinrich Ehinger e Bartolomeu Welser (Haebler 1892: 52)). Levar-nos-ia por demais longe relatar os primórdios da escravidão negra em São Domingos e por conseguinte da América. Basta dizer que já em 1510 houve uma permissão para levar escravos negros a São Domingos ${ }^{30}$. Em 1518 um favorito, Laurence de Bresse, governador de Bresse recebeu a permissão de enviar 4.000 escravos a São Domingos sem pagar aduana ou outro imposto. Esse governador de Bresse arrendou o direito a diversas pessoas interessadas. Em 1522-1523 ele recebeu nova licença para 4.000 escravos, devendo a metade ser formada por mulheres (Haebler 1892 e Panhorst 1928). Os colonos, entretanto, se queixaram à coroa e o resultado parece ser o asiento de 1528 que permite aos Welser o transporte de 4.000 escravos nos primeiros quatro anos. Certamente antes de 1528 já participaram desse comércio, pois se não tivessem experiência, não se teriam lançado a esse empreendimento do qual 1/3 devia ser constituído por mulheres. Os Welser deviam pagar como imposto a soma global de 20.000 ducados, portanto 5 ducados por escravo. Deram imediatamente uma parte da soma, o resto foi pago em parcelas nas feiras de maio e de outubro. A coroa por seu lado prometeu não conceder a ninguém licença para levar escravos, somente os novos colonos podiam levar consigo dois escravos para a América. Conforme o tratado, os Welser não podiam cobrar mais que 50 ducados por escravo ${ }^{31}$. Conhecendo bem as desvantagens do pagamento a crédito, conseguiram que o pagamento devesse

\footnotetext{
${ }^{29}$ Haebler (1892: 52). Os três irmãos Ambrósio, Heinrich e Ulrich Ehinger são representantes ou sócios dos Welser.

${ }^{30}$ Colécción de documentos inéditos de Ultramar, série II, vol. 5, p. 199.

${ }^{31}$ Haebler (1892: 557) acha que talvez o preço na colônia seria de 55 ducados, incluindo-se a taxa.
} 
ser feito a vista, não precisando esperar mais que 14 dias num porto para vender os negros (Haebler 1892: 81). A maior parte desses escravos provinha da Guiné portuguesa. Assim permitiu-se aos Welser que fizessem o transporte em navios portugueses (só esses podiam chegar até a Guiné), não deviam, entretanto, levar mais que três portugueses a bordo; como isso se mostrou impraticável, permitiu-se então 1/3 de portugueses, que não podiam, porém, baixar a terra na América. $\mathrm{Na}$ ida não precisavam tocar em Sevilha, mas na volta isso era necessário, pois, se para os escravos não tinham que pagar mais impostos, as mercadorias que traziam da América não estavam isentas de taxas. Em junho de 1529 receberam ainda licença para transportar mais 800 escravos além dos 4.000. Esses 800 eram destinados aos 400 colonos da Venezuela. A colonização da Venezuela, como veremos adiante, foi um fracasso, assim pediram em 1532 permissão para poder vender os escravos que sobraram em outros portos. Os Welser não conseguiram manter o prazo de 4 anos para a remessa de 4.000 escravos. Não há muita documentação sobre esse comércio, não se tem certeza se após o período 1528-1532 houve novos asientos, ou se a continuação dos alemães nesse comércio é apenas permitida para completarem a cifra estabelecida pelo asiento de 1528. Panhorst afirma que em 1532 o feitor dos Welser, Christoph Heslin, conseguiu novo contrato para mais 4.000 escravos nos 4 anos subsequentes ${ }^{32}$. Em todo caso, em 1538, os Welser ainda tinham interesse no comércio escravagista e obtinham grandes lucros, pois nesse ano pagaram a soma de 10.000 ducados ao arqueduque Ferdinando soma essa relacionada com o tráfico

\footnotetext{
${ }^{32}$ Panhorst (1928: 124). Esse autor exagera o número de escravos transportados pelos Welser; segundo seus informes, de 1528 a 1532 foram transportados 4.800 aproximadamente. Mesmo não havendo dados, Panhorst acha que depois de 1532 a cifra foi de 3000. Continuando seu raciocínio bastante perigoso, afirma que para quase 8000 escravos eram necessárias 45 viagens de navio. No entanto, numa carta de janeiro de 1531 dirigida ao Conselho das Índias, o imperador afirma que está de acordo com o Conselho sobre o contrato de escravos negros com os alemães e que acabado o prazo não se devia prorrogar o mesmo nem fazer um novo... "Y asy conosciendo el daño que desto sea seguido a las dichas yndias no he tomado asyento ny dado cartas ningunas para pasar esclavos ni entiendo de alla: vosotros no las dyas alla, sin consultar me primero e tener especial mandamiento mio por ello". Esse documento foi publicado por Medina em 1889.
} 
de escravos. É quase impossível essa soma ser ainda resultado do asiento de 1528 (Haebler 1892: 84). Este historiador encontrou no Archivo General de Indias documentos sobre um projeto de 1536 referindo-se a nova remessa de escravos para São Domingos. Não se pode porém ver se os Welser estavam ligados a este projeto, pois as diversas cópias com nomes diferentes não permitem chegar-se a uma conclusão definitiva. Nesse projeto as taxas foram elevadas a 6,5 ducados por cabeça, perfazendo a soma de 26.000 ducados que deveria ser paga imediatamente. Isso vem provar que o comércio de escravos negros deve ter dado lucros satisfatórios, senão gigantescos aos Welser e seus associados quando eram os monopolistas. Parece que os Welser participaram desse comércio até o fim de sua aventura venezuelana (Panhorst 1928: 130). Os processos que a coroa ou a Audiência de São Domingos promoveram contra os Welser devido ao não cumprimento do tratado de 1528 e os processos contínuos que esses banqueiros alemães tiveram de mover contra os colonos que infringiam o seu monopólio, fizeram que pouco a pouco se desinterassem por esse comércio. Panhorst acha que também os Fugger estavam ligados ao tráfico de escravos negros, pois em 1536 são encarregados de organizar um empréstimo dos escravagistas ao Conselho das Índias. Está comprovado que os Fugger mantiveram na ilha de São Domingos um representante.

Não se sabe muito sobre o destino dos escravos transportados para a América pelos alemães. Para a redistribuição a partir de São Domingos devem ter sabido aproveitar a conjuntura econômica dos portos, bons comerciantes que eram. Naturalmente certo número foi levado à colônia dos Welser, a Venezuela. Além do tráfico com escravos negros, a feitoria não estava alheia ao apresamento e à escravização de índios. Como veremos mais tarde, a iniciativa da colonização da Venezuela partiu de São Domingos, onde se conheciam as grandes possibilidades quanto à caça do índio naquela região.

A mineração e principalmente o transporte de mineiros alemães constituíram um interesse todo especial para a feitoria de São Domingos. Houve um asiento dedicado ao transporte de mineiros alemães para São Domingos; entretanto, o documento nunca foi encontrato. Há, porém, referências a esse transporte no asiento de 
12 de fevereiro de 1528 sobre os escravos negros. Conclui-se, portanto, que o contrato sobre os mineiros deve ter sido o primeiro daquela série que os Welser conseguiram em 1528. O asiento sobre a doação da Venezuela refere-se igualmente ao transporte de mineiros alemães para a América. Embora poucas, as condições estabelecidas no contrato sobre a Venezuela devem ter sido senão iguais, pelo menos semelhantes às do asiento original; por isso transcrevemos aqui o que estipula a carta de doação da Venezuela:

\footnotetext{
"seais obligados a pasar a las islas Española, Sant Juan y Cuba y a la dicha vuestra tierra y a otras cualesquier partes de las nuestras Indias y tierra firme e a las islas nuestras, dentro del dicho termino de los dichos dos años cincuenta alemanes naturales de Alemanis, maestros mineros a vuestra costa, Para que con su industria y saber se hallen las minas y veneros del oro plata y otros metales que oviere en las tierras e islas, e los repartir por ellas como a vosotros pareciere ques mas provecho nuestro; y que en el buen tratamiento, litertad y execucion que han de tener los dichos alemanes, se guarde lo mismo que están otorgado a los mineros alemanes que residen en Galicia, en los mineros de aquel reino".
}

Em 1528 foram levados para a América 24 mineiros, e no ano seguinte mais 25 procedentes na sua maioria de Jaochimstal e alguns de Schwaz. Parece que uma parte desses mineiros foi levada para São Domingos pela primeira frota que os Welser enviaram para a Venezuela. A maior parte, entretanto, veio com Nikolaus Ferdermann (Panhorst 1928: 114 e Haebler 1892: 63). Os mineiros alemães não se deram bem na América, em parte devido ao clima, em parte devido ao descontentamento com o tratamento que lhes foi dispensado pelos Welser. Queixaram-se às autoridades e os processos permitem verificar muitos pormenores sobre sua estadia na América (Panhorst 1928: 113). A maior parte era originária da Saxônia; foram levados às custas dos Welser até Antuérpia. A maioria dos itens do contrato entre os Welser e os mineiros foram organizados em Sevilha e não na pátria desses mineiros. Estipulava esse contrato que, como a terra e o trabalho fossem desconhecidos, não receberiam soldo nos primeiros três meses, mas apenas o necessário para a vida; o regulamento de trabalho deveria ser discutido no local por um representante dos mineiros 
e o feitor dos Welser; a companhia prometia que depois de descontadas as despesas da viagem e da manutenção, os mineiros participariam com 1/6 do lucro; o mineiro que não se desse bem com o clima receberia um auxílio para poder voltar; na viagem teriam que servir como marinheiros e em caso de necessidade como soldados; um dos mineiros podia levar a esposa para lavar e cozinhar para todos. Muitos lançaram mão da cláusula sobre o retorno e pediram uma indenização ${ }^{33}$. Os documentos existentes não dão informações precisas se o transporte dos mineiros para São Domingos foi lucrativo para os Welser. Sebastian Rentz, feitor dos Welser em São Domingos, diz que até 1534 foram gastos com os mineiros quantias que correspondem a 3.800 florins renanos e Bartolomeu Welser, certamente por estar interessado no processo, exagera, dando a soma de 10.000 florins renanos. Mesmo essas somas estando certas, não deve-se tratar de capital perdido, mas somente gasto e que sem dúvida, deve ter rendido juros. Parece que esses mineiros se espalharam pelas diferentes regiões banhadas pelo mar das Antilhas.

Com relação à lavagem de ouro na própria ilha de São Domingos existem muitas dúvidas; Haebler (1892: 60) diz: “ocasionalmente foi afirmado que também os Welser mantiveram lavagens de ouro em São Domingos, e que ai se tornaram culpados da costumeira crueldade contra os indígenas. Documentos que provem essa afirmação não consegui encontrar”. Em São Domingos foram descobertas minas de cobre; são as minas de Cotoy (Haebler 1892: 64). Mas devido à falta de especialistas não pode ser verificado se valia a pena explorá-las. Um mineiro alemão fez mais tarde um relatório favorável. Criou-se então uma espécie de sociedade com o feitor dos Welser, o mineiro alemão e um habitante de São Domingos, provavelmente um dos veintiquatro de São Domingos. Em 1540 a Audiência deu a permissão para o início da exploração. Não há mais referências ao empreendimento nos documentos, apenas de vez em quando cita-se o cobre como uma das mercadorias dos Welser

\footnotetext{
${ }^{33}$ Haebler (1892: 64); esse autor acha que a maioria, entretanto, se mostrou satisfeita com os Welser.
} 
(Haebler 1892 e Panhorst 1928). Todas as tentativas de mineração empreendidas por alemães na América Central e regiões vizinhas tiveram seu ponto de partida em São Domingos. Os alemães realmente se destacaram nesse setor, basta lembrar os diversos livros sobre mineração que foram traduzidos para o espanhol na América no século XVI. Os célebres Cromberger, por exemplo, imprimiram vários livros no México.

São Domingos foi de máxima importância para os empreendimentos alemães e particularmente para os dos Welser na América. São Domingos foi o ponto a partir do qual se expandiram para quase todas as regiões da América Central; foi de lá que os Welser se lançaram à colonização da Venezuela; foi a feitoria dessa ilha que facilitou a exploração econômica da Flórida, do México, de Cuba, de Haiti, etc. São Domingos despertou nos alemães, e principalmente nos Welser, o interesse pela América. Já vimos que essa feitoria dos Welser deve ter funcionado até 1540 ou 1542. Seu abandono, segundo Panhorst (1928: 169), se prende à preferência em estabelecer relações comerciais diretamente com os diferentes portos.

Em Cuba encontramos alemães ligados à exploração das minas de cobre. A principal figura foi um tal Hans Tetzel. Parece que agiu independentemente, não estando ligado aos Welser. Apareceu em Santiago de Cuba com uma carta de recomendação do imperador Carlos V. As autoridades coloniais tiveram muito trabalho com ele, daí a abundante documentação sobre sua atuação de 1546 a 1550. A 11 de janeiro de 1546 fêz-se o "asiento con Juan Tecel, alemán, para explotacion de las minas del cobre" (Haebler 1892: 66 e Panhorst 1928: 119). Tetzel tinha descoberto um bom método para a exploração das minas de cobre e os habitantes de Cuba queriam que ele revelasse o segredo; procuraram entrar em entendimentos com Tetzel. O relatório de maio de 1548 que o governador, Juan de Agramonte, mandou ao imperador ilustra o problema do entendimento de Tetzel com as autoridades:

"En lo del cobre Juan Tecel aleman, a quien vuestra Magestad hizo merzed, se a avido tan floxamente, que en un año que a questá en esta ysla casi es nada lo que a hecho. A procurado de hazernos sus tributarios ean dezir que si avimos de fundir cobre los vecinos dela ysla le aviamos de pagar trebuto por siempre, de veinte 
quintales uno, y questo aviamos de traer nosotros confirmado de vuestra Magestad, y hasta questo toviese hecho, no a querido fundir ni dexado ver a nadie su fundicion, delo qual los vecinos desta ysla an estado my escandalizados y le an hecho ciertos requerimentos, diziendo que manifieste el secreto que trae para fundir el cobre dulce y se le pagará lo que fuere justo, y él pide tanto que a todos pone grima, y asi no se a hecho partido ninguno con él. Ahora ocho dias quel governador Antonio de Chaves y los oficiales de vuestra Magestad fuimos a la fundicion del dicho cobre, y mas por fuerça que voluntad del dicho Juan de Tecel, vimos fundir obra de dos quintales de cobre dulce. Va en este navio a los oficiales de la casa de contratacion de Sevilla para que ellos lo hagan labrar e eyformen a vuestra Magestad delo que tiene el dicho cobre, y esto sea proveydo porque no ay acá quien sepa labrar. A vuestra Magestad suplico, pues hage merced, sea quin perjuicio de los vecinos desta ysla, quel dicho Juan Tecel dize a de procurar de alcançar de vuestra Magestad grandes mercedes para quel pueda hazer en lo del cobre lo quel quisiere" ${ }^{34}$.

A 27 de junho de 1550 chegou-se finalmente a um acordo:

"Refiérese como este aleman habia dos anos que fue, en virtud de capitulacion con S. Magestad á beneficiar el cobre, y sobre si habia ó no de manifestar á, los vecinos el secreto de fundirlo, de modo que se pudiese buenamente Labrar, se habian ocasionado muchas diferencias y se temian albarotos. De aqui el convenirse en los seguintes capitulos:

Juan Tecel se obliga de ensenar todo el arte de sacar, fundir y aducir el cobre á cualesquier esclavos que se le entreguen, dentro de ano y medio, encuyo tiempo estos trabajem para él, y él los mantenerá, y cuando no saliesen bien enseñados, él pagará por cada á 30 pesos él ano, sino en caso que antes de cuatro meses el hubiere dicho ser inhabil.

Antes de ninguno ha se exorger Tecel y estacar dos minas en el cerco del cobre; de todo lo demas que vecinos sacaren, ha de mevar [?] tres por ciento perpetuamente, él y sus sucessores, en recompensa de los gastos, tiempo y ingenio aplicados á su invencion, todo sin perjuicio de las mercedes que tiene en la capitulacion con S. M.

\footnotetext{
${ }^{34}$ Coleção de documentos de Ultramar, série II, tomo VI, p. 306.
} 
Obliganse los contratantes a pedir confirmacion con S. M. dentro de año y medio, y que entren en el contrato los demas pueblos de las islas. Dr. G. Perez de Angulo, Gobernador $=$ Francisco de Parada, su teniente general $=$ Francisco de la Bandera, Alcalde $=$ Andres Escribano, alcalde $=$ Alonso Hurtado, alguecil mayor $=$ Hernandes de Medina = Juan Velasquez de Ledesma, regidores $=$ Hernando Orejon procurador general = Antonio de Zorita, escribano" $"$.

O interessante é que depois dessa data não há mais referência às atividades de Tetzel. Foi ludibriado pelas autoridades espanholas? Trata-se de um dos mineiros vindos com os Welser para São Domingos? Tornou-se independente? Como veio à América?

$* * *$

Partindo de São Domingos os Welser se dirigiram para Nova Espanha onde foram explorar as minas de prata na vizinhança de Zultepeque. Parece que os Welser foram particularmente ativos na mineração de prata no México (Haebler 1892: 60 e Haring 1947: 316). As minas propriamente ditas de Zultepeque pertenceram aos Kromberger, famosos impressores na península Ibérica e que organizaram no México a primeira imprensa da América. Parece que essas minas desde cedo "fueron de los alemanes", portanto, como conclui Haebler, dos Welser, pois em documentos as palavras "los alemanes" referindo-se a uma firma comercial sempre foram usadas para designar os Welser. Não há, entretanto, documentação sobre quando os Welser conseguiram essas minas. Existe um documento de 1542, uma petição para a concessão de terras aos sucessores menores de Hans Kromberger a quem pertenciam as minas "que fueron de los alemanes" (Panhorst 1928: 117). Parece que Kromberger não tinha obtido as minas muito antes de 1542. Nas minas além de escravos negros e índios, havia também funcionários europeus. Trata-se de mineiros alemães, como se vê na declaração de prestação de contas da Audiência (Panhorst 1928: 118). Além desses alemães, encontramos também vestígios de atividades dos Fugger no México. Parece que por volta de 1530 se estabeleceu em Yucatan um certo Sebastian Kurz (Haebler

\footnotetext{
${ }^{35}$ Coleção de documentos de Ultramar, série II, vol. VI, p. 314.
} 
1897: 52). Como Sebastian Kurz esteve a serviço dos Fugger até 1552, pode-se supor que tenha empreendido a viagem ao Yucatan a serviço dos Fugger. Sobre suas atividades em Yucatan não há notícias, mas Haebler (1895: 366) tinha esperança de "talvez um dia conseguir descobrir com essa pista outros empreendimentos transoceânicos dos Fugger".

Como já vimos, desde o fim do reinado de Carlos V e particularmente durante o reinado de Filipe II, foi pouco a pouco proibida a vinda de estrangeiros para a América, mesmo que a vinda de um estrangeiro só trouxesse vantagens. Bartolomeu de Medina quis levar para o México um mineiro alemão por volta de 1554 "que sabe beneficiar los metales de plata con azogue a gran vantaja de lo que aca se hace y sahe [...] parece seria gran riqueza da venida del aleman si oviese azogue" não permitiu sua vinda, apesar da insistência da Audiência de São Domingos.

O Peru, sendo uma região riquíssima, não podia deixar de interessar aos banqueiros alemães. Já em 1525 os Fugger receberam privilégios, tendo mesmo fundado alguns povoados (Clough-Cole 1941: 208). Há constantemente referências aos Fugger em contratos sobre minas peruanas, aparecendo as empresas dos Fugger sempre como exemplo digno de ser seguido. Na mina de Huancavelica, por exemplo, queriam seguir a organização dos Fugger. Tiveram em 1580 a idéia de organizar um sistema de monopólio de todas as minas de prata e ouro no Peru. O interessado nessa empresa, Ventura Espino, "a quien se queria hacer el Fugger peruano”, contratou especialistas em Almaden, as célebres minas dos Fugger na Espanha, para organizar as minas de Huancavelica a exemplo das de Almaden. Vieram como especialistas na fundição de mercúrio Guilhermo Engelbert e seu filho Arnaldo e mais vinte oficiales (Lohman Villena 1949: 37-60).

\footnotetext{
$* * *$
}

\footnotetext{
${ }^{36}$ Costuma-se atribuir a Medina a invenção do processo de extração de metais preciosos por meio da amálgama. Na realidade aprendeu o processo com um mineiro alemão, na Espanha (Haring 1939: 199 e Hering 1944: 388).
} 
Os Fugger se interessaram muito menos que os Welser pelos negócios coloniais. Mais práticos, nunca se interessaram por empreendimentos duvidosos. Mas a partir de 1530, também quiseram lançar-se à aventura colonial. Talvez tivessem se entusiasmado com o empreendimento dos Welser na Venezuela. Interessaram-se pela costa do Chile atual. À primeira vista uma empresa colonial como outra qualquer, mas com uma análise mais profunda dos documentos, percebe-se que queriam a costa do Chile, é verdade, mas a causa verdadeira era a posse das ilhas do Pacífico até a linha de demarcação entre as terras de Portugal e de Espanha, ilhas essas onde imaginavam encontrar especiarias e que julgavam próximas da costa.

Em 1530 houve entre Veit Hoerll, o Vido Herll dos documentos espanhóis, feitor dos Fugger e o Conselho das Índias longas conversações sobre a doação da costa do Chile "desde el estrecho de Magallanes hasta el pueblo de Ghincha". A maior parte das petições de Hoerll e das respostas do Conselho das Índias chegaram até nós. Esses documentos, devido as suas minúcias são de extrema importância, pois dão uma idéia clara sobre como pensavam e agiam os Fugger em relação aos problemas coloniais. Mostram por parte dos Fugger e de seu representante um profundo conhecimento das condições na América. Isso prova que apesar de termos poucas notícias sobre as atividades dos Fugger na América, eles devem ter tido uma série de feitores ou agentes no Novo Mundo. Os documentos dessas conversações ilustram de maneira eloqüente a política colonial da primeira metade do século XVI. Revelam uma profunda segurança no tratamento dos problemas coloniais ${ }^{37}$. Os Fugger, entretanto, não se contentaram com o que Veit Hoerll conseguiu e contestaram as restrições impostas pelo Conselho das Índias numa carta dirigida diretamente ao imperador:

"Anton Fugger y Companhia dicen: Que Vido Herll su factor, que reside en Espana, dió una peticion en el Vuestro Consejo de las Indias, en que declaró los

\footnotetext{
${ }^{37}$ Medina (1889: 278-287). Os documentos encontram-se no Archivo General de Indias; Acta Patronata 1-2; 1/28. Levar-nos-ia por demais longe relatar, mesmo que resumidamente, o que Hoerll ou os Fugger pediram em seus diferentes requerimentos.
} 
capitulos y condiciones con que ellos se han de encargar de la conquista y descubrimiento y poblacion de las tierras é yslas de las Indias que hay desde el Estrecho de Magallanes hasta la tierra de Chincha y Chiquilus Melares, conforme á lo que se ha platicado, porche el dicho su factor no estaba bien informado del negocio, y los del Vuestro Consejo respondieron á ellos y concedieron lo que les pareció, de lo qual el dicho factor no fué contento. Suplican á V. M. mande tornar á ver esta peticion, en la qual se contiene á la letra el dicho memorial y capitulos que dio su factor con las respuestas ó declaraciones hechas por el Consejo de las Indias y juntamente con elle declaran y dicen agora más particularmente de la manera que quieran encargar se de la dicha conquista y con qué asiento y condiciones y pues en todo se conforman con la razon y no piden sino cosas justas y razonables y cosas que se han concedido á, otros, suplican á V. M. se las mande conceder á ellos esta su conquista y descubrimiento he de ser my más lexos de Vuestros Reynos de España y más peligroso el viage y el Estrecho que han de pasar, que ninguna de las conquistas que hasta agora se han hecho y donde ponen su hacienda á mucho más riesgo que otros ningunos....”38

O imperador Carlos V a 3 de abril de 1531 enviou o pedido dos Fugger ao Conselho das Índias para que considerassem os pedidos dos banqueiros e de seu feitor. Hoerll trabalhou ativamente e conseguiu que grande parte de suas exigências fôssem concedidas. Conseguiu muito maiores vantagens que as que os Fugger tinham pedido. Juan de Samano, secretário do Conselho das Índias, estudou o caso e em seu relatório encontramos as condições definitivas do acordo sobre a colonização do Chile pelos Fugger:

"Al primero: que se entienda que la Gobernacion es todo lo que hay desde el comienzo del Estrecho de Magallanes hasta los fines de la Gobernacion de Pizarro y que entre la tierra adentro doscientas leguas, medidas desde la costa por cordillera y que las yslas que descubrieren en este parage dentro de quatro años, desde el dia de la fecha de la capitulacion, se entiendan en ella.

Dicen los Fúcares, tocante al segundo capitulo, que por servicio de V. M. é bien de la negociacion se obligarán de enviar á esta conquista, en los tres primeros viages, á su costa, los quinientos hombres que V. M. les requiere que envien,

\footnotetext{
${ }^{38}$ Medina (1889, vol. III) e Panhorst (1928: 278-287).
} 
con tanto que no sean obligados de enviar la segunda ni tercera hasta que aquella primera armada sea vuelta en los puertos de España, no lo queriendo hacer de su voluntad, é que si venida la respuesta de la primera armada, no tujere de la dicha tierra é yslas buena relacion, que sea á su conciencia tornar á armar ó no para las partes susodichas.

A1 segundo: Que se entendienda así, con tanto que, dentro de tres meses despues de venida la primera armada, ellos sean obligados á declarar si quieren tornar á armar y que si no lo declararen, que S. M. pueda, pasado el término, apremiarlles ó dar licencia á otras personas para armar.

Tocante al tercero capitulo, suplican que esta gobernacion se les conceda por tres vidas y que Antonio Fucar sea el primero é que él pueda nombrar otro para despues de sus dias y el que por él fuere nombrado pueda nombrar otro subcesor de la misma manera, é que estos tres, no yendo ellos en persona á las tierras é yslas de la dicha conquista é governacion, la persona ó personas á quien ellos dieren su poder uso del oficio del gobernador y en su ausencia en las dichas tierras é yslas como ellos mesmos, sin que sea necesario haber cada vez confirmacion de S. M. de tal nombramiento, pues para tal empresa no han de nombrar ellos ni encomendar su hacienda é honra sino á personas calificadas é de recaudo, de quien V. M. puede ser bien servido, é que V. M. haya por bien de no les facer sacar ninguna cosa de los quentos de maravedis á su salario en cada año por la dicha gobernacion, pues esto se ha de pagar de lo que se ganare.

Al tercero: Fiat, con que el nombrado sea obligado á llevar permision de S. M. dentro de un año que fuere nombrado, y que el salario sea dos mill ducados y dos mill de ayuda de costa.

Tocante al quarto capitulo, suplican que las fortalezas que se les han de dar perpetuas sean quatro con ciento é cincuenta mill maravedis de salario, que los del Vuestro Consejo señalaron, é que las dos sean en puertos de naos, pues los pueblos han de ser de V. M.; é las otras dos fortalezas sean de las que hicieren en tierra firme, pues la conquista es grande y en mucha tierra es necesario que se hagan muchas fuerzas. En las demás que se hicieren, se les dén por las tres vidas susodichas, é la paga de la gente son contentos que sea á parecer de los Oficiales de V. M.

A1 cuarto: que bien está respondido, con que el salario sea ciento y cincuenta mill maravedis en cada ano. Tocante al quinte capitulo, dicen que si hay alguna de las personas que ellos o subcesores nombraren para los oficios de justicia é Regimientos y Escribanias pareciere á los Oficiales de V. M. que agora han de ir é á los que por tiempo estovieren en las dichas tierras é yslas de su conquista que no son bien qualificados, ni tienen las partes que deberán de tener para tales Oficios, que los mismos Fúcares quiten á las tales é tornen nombrar otros en su 
lugar é sindo aquellos aprobados por los dichos Oficiales de V. M., que las tales personas envien entónces por la confirmacion de sus Oficios á V. M.

Al quinto: Que está hien lo que está respondido, porque si alguno hiciese lo que no deve, él puede hacer justicia dél.

Tocante al sexto capitulo, suplican que de les conceda la décima parte de lo que conquistaren y pacificaren con las condiciones que yo he pedido, que ni sea en lo mejor ni en lo peor de las dichas tierras é yslas de su conquista, para que si en el repartimiento de la dicha décima parte de tierras é yslas estrare algun puerto de mar, que se les conceda poderlo tener, pues lo uno é lo otro é todo se ha de descubrir é conquistar é pacificar e poblar á su costa dellos. E que la jurediccion cevil é criminal de las dichas tierras é yslas que quedaram por tengan el senorio, como lo tienen en suas tierras los Senores aqui en Castilla.

A1 sexto: Que está bien respondido, con que sea la quincena parte y que esta no pase treynta leguas, con jurisdiccion conforme à la respuesta, y que en lo demás tengan el senorio, como lo tienen en sus tierras los Sres. aqui en Castilla.

Tocante al seteno capituto suplican á V. M. que se les conceda este capítulo como yo lo he pedido, pues dello redundará mucho servicio á V. M. e bien é utilidad á sus subditos é vasallos. E piden due esto se mande so graves penas que ellos é sus lugartenientes sean meros executores dellas, é dicen que en quanto á lo que se les respondió por los del Consejo, para que ellos nombren conquistadores hábiles, sin les llevar cosa alguna por ello, no entienden esta respuesta, ni ellos quieren tener personas en esta negociacion sino muy hábiles é que vayan á conquistar libremente; pera no quiéren que gentes de otra provincia vayan á la suya sin su licencia, pués está en otras bien experimentado el daño que dello se sigue; y esto mismo se ha concedido á otros conquistadores.

Al setimo que está bien respondido.

Tocante al otavo capítulo, suplican que a estos nuevos pobladores de su conquista se les concedan algunas gracias y prerogativas y más de las ordinarias, siendo justas é honestas y que estas queden para poderles decir é declarar dentro en el término del dicho su descubrimiento.

Al octavo: Fiat.

Tocante al noveno capitulo, suplican que por veinte anos no paguen mas del diezmo de todo, asi del oro y de Minas, como de rescates é entradas é cavalgadas y cumplidos los veynte anos que se quede en que hayan de pagar el quinto; pero que todavía el primer viage quede horro é libre de todo derecho, y despues comiençen á correr los dichos veynte anos del dicho diezmo.

Al noveno: que del oro de las minas paguen el primero ano el quinzavo, el segundo, el quatorceno y así bajando hasta quedar en el quinto, y que de todo lo cogiere de cavalgadas paguen el quinto. 
Tocante al deceno capítulo, suplican a V. M. presente á las Dignidades que se instituyeren en las tierras é yslas de su conquista las personas que ellos nombraren, teniendo todas las calidades que para ello se requiere, y que esto sea solamente por el tiempo que duraren las tres vidas contenidas en el tercero capítulo y que los Obispados queden á eleccion é presentacion de V. M.

Al décimo: Que está bien, y que S. M. terná consideracíon a esto que suplican. Tocante al onceno capitulo, suplican que se les conceda para siempre á ellos é á sus herederos é subcessores el jus patronatus de los beneficios que se instituyeren en la decima de tierra é yslas que se les ha de dar de lo que conquistaren, pues es justo que séan patronos y con justo títolo lo pueden ser los que son conquistadores y pobladores de las tales provincias, presentando personas hábiles é suficientes, a contentamiento de los Obispos é prelados que hobieren por tiempo en las dichas tierras y yslas y que de todos los beneficios, de lo demás de la tierra de su conquista, sea S. M. el patrono, excepto en lo de las tres vidas que han pedido en el capítulo ántes deste.

Al undecimo: Que S.M.; les concedera en la Iglesias que ellos fundaren quanto les pertenciere y conpliere.

Las cosas que piden los fúcares, de mas de los que los he pedido, son estas. Primeramente piden que, el tiempo del dicho descubrimiento haya de durar seis años más de lo contenido en la primera capitulacion que tengo presentada, que son en todo doce años.

Respuesta á las otras peticiones: A la primera: Que sean ocho años.

Que se les conceda e1 título de Adelantado perpetuamente de las tierras é Yslas de su conquista, sin salario, como se ha concedido á otros conquistadores.

A la $2^{\circ}$ : Fiat.

Que se les dé asimesmo perpetuamente el Oficio de Alguacil Mayor de las dichas tierras é yslas de su conquista, como se ha dado á otros conquistadores, sin salario, salvo que solamente lleven su derecho, conforme á las Ordenanzas, y tengan las otras facultades y prerogativas que los Alguaciles mayores suelen tener.

A la tercera: Fiat por las tres vidas.

Que se les conceda el título de Capitan General por las tres vidas de suso contenidas, juntamente con el título de Gobernador pues por ello no pidan acrecentamiento de salario y se ha concedido á otros con salario.

A la quarta: Fiat.

Suplican que se les haga merced que se les conceda perpetuamente para ellos y para sus herederos, en remuneracion del trabajo, que han de tener en esta conquista é de los grandes gastos que han de hacer en ella á su costa, la décima parte de todo el provecho é rentas que V. M. tuviere en qualquier manera de las dichas 
tierras é yslas de su gobernacion y conquista, sacando primeramente dél todas las costas é gastos que por parte de V. M. se hiciera en ello é los salarios de Oficios y Tenencias é otras cosas desta calidad, como se ha concedido é otros.

A la quinta: Que tengan quatro por ciento de todas las Rentas que S. M. dehiere sacar, con que no pasan de dos mill ducados en cada un año.

Otros si suplican que de todo que llevaren de Flandes, como de España de bastimentos e vituallas é armas é municiones para la gente que pasa en la dicha conquista en la primera armada é desde adelante hasta doce años cumplidos luego siguientes, no hayan de pagar, ni paguen, derecho de Almojariridfazgo, di diezmo, ni alcabala, ni otro derecho alguno, é que lo que llevaren para las personas y casas de los que estuvieren por Gobernadores en la dicha conquista no se les lleven derechos, durante las tres de suso contenidas.

À la sexta: Que por diez años sean Iibres, como lo piden, y lo que para sus personas y casas lleven hasta en dos mill pesos de valor cada un año.

Item, que durante el tiempo de su descubrimiento, M. M. no dé licencia a ninguna persona para descubrir a la dicha conquista, continuando ellos el dicho descubrimiento, segun su asiento.

À la sétima: Fiat.

Otrosi, piden que durante el tiempo de los doce anos del dicho contrato, V. M. no haya de encomendar á persona ni personas algunas, los Indios de la dicha tierra é yslas que asi descubriren, salvo que se estén é vivan en su libertad, para mejor tratamiento é hacer experiencias dellos, porque en tenerlos por esclavos se han seguido hasta aquí muchos inconvenientes.

À la octava: Fiat.

Otrosí, suplican que V. M. lés dé licencia para llevar de qualquier tierra é ysla de S. M., para la dicha tierra é yslas que descubrieren, todos los caballos é yeguas é otros ganados que ovieren menester, sin les ser puesto embargo ni impedimiento alguno. À la novena: Que pueden llevar de Castilla cinquenta caballos, con que el un tercio sean yeguas. Otrosi, piden licencia para llevar para la dicha tierra é yslas, de Portugal, Cabo Verde é isla San Tomé fasta trescientos esclavos, el un tercio mujeres é los otros dos tercius hombres, libres de todos los derechos, y esto se entiende que no sean para vender, salvo para el servir in y trabajo de la dicha negociacion, é haciendo lo contrario, que queden perdidos.

À la decima: Fiat.

Otrosí, suplican á V. M. haga merced á su nombramiento á uno ó dos Pilotos é así á un Calafate é a un Carpintero, que allá ovieren de vivir de salario cada un año sí cada Piloto de ochenta mill maravedís é al calafate e carpintero quarenta 
mill maravedis á cada uno dellos, por cada un ano, pagados por los Oficiales de V. M. é de sus Rentas de la dicha tierra.

À la undécima: Fiat, el Piloto de quarenta mill maravedis y el Calafate veinte mill.

Outro si, piden que ninguna persona prohibida, ni letrado ni Procurador, para usar de su oficio, pueda ir en la dicha conquista, so la pena que V. M. fuere servi-lo.

Otrosi, piden que V. M. haya por bien de hacer merced á los Hospitales que con el tiempo en la dicha ysla ovieren, como á otros fueron concedidos, de los derechos de escobilla é relaves que oviere en las fundiciones que en la dicha tierra é islas se hicieren.

Otrosi piden que por tiempo de su descubrimiento, les seam dada lugar en las atarazanas de Sevilla, en que pueden tener las cosas que ovieren de llevar é cargar para la dicha tierra y yslas, en el tiempo del dicho su descubrimiento.

A la duodecima, decima-tercia y cuarta: Fiat" ${ }^{39}$.

Hoerll ainda conseguiu modificar alguns itens. Todos os itens foram muito bem estudados tanto pelo Conselho das Índias, como por Hoerll. Não seria por falta de concessões, facilidades e vantagens que os Fugger iriam fracassar na colonização da costa do Chile. Segundo Haebler (1897: 67), em meados de 1531, após longo período de preparação e de discussão, tudo estava regulamentado quanto ao projeto colonial. O destino desse projeto é desconhecido. Organizaram a primeira frota? Desistiram antes de empreender a primeira expedição? Haebler afirma que não encontrou a mínima indicação no Archivo General de Indias em Sevilha e nos arquivos dos Fugger. Panhorst (1928: 291-4) em suas pesquisas encontrou um relatório no Archivo General de Índias onde se fala de um acordo "que hizo el emperador con los Fucares y Alcazaba". O documento ainda diz que Alcazaba estava de acordo com todos os preparativos que os Fugger fizeram para terem sucesso nas descobertas. O relato se refere a uma tempestade e a um naufrágio. Panhorst, apesar de afirmar que o documento é muito pouco claro e que provavelmente se trate apenas

${ }^{39}$ Medina (1889, vol. III) e Panhorst (1928: 278-287). 
de fragmento de relatório maior, presume referir-se a uma expedição ao Chile. Tratando-se realmente de uma expedição ao Chile dos Fugger juntamente com Alcazaba, então o imperador deve ter ratificado o acordo. Não continuaram a empresa por causa do naufrágio? Já que não temos notícias positivas sobre a causa do abandono do projeto, mais certo é supor-se que os Fugger obtiveram notícias de que as almejadas ilhas estavam situadas muito longe da costa. Além disso, ainda não se tinha certeza se as ilhas por direito caberiam a Portugal ou a Espanha. E o interesse dos Fugger não estava na costa do Chile e sim nas ilhas. Num dos pedidos de Veit Hoerll temos:

“... si por caso desde el Estrecho de Magallanes hasta el pueblo de Chincha o desde el dicho Estrecho de Magallanes hasta llegar á Maluco, a qualquier parte que sea, de la una costa á la otra, sin entrar ni tocar en tierra de Maluco, ni en cosa tocante a la capitulacion y particion que está hecha con el Serenísimo Rey de Portugal, ni tampouco tocando en tierras é yslas que hasta agora estén concedidas á otras personas, se hallaren o descubriren algunas yslas o tierras demás de lo contenido y especificado en el dicho primer capitulo que los dichos Fúcares lo puedan conquistar y poblar como en el dicho capítulo se contiene". ${ }^{40}$

Também os Fugger, escrevendo de Augsburgo ao imperador, pedem expressamente a concessão dessas ilhas:

“... que si por caso, desde el Estrecho de Magallanes hasta llegar á Maluco ó á qualquier parte que sea de la una costa á la otra, sin entrar ni tocar en tierra de Maluco, ni en cosa tocante á las capitulaciones y particion que está hecha con el Rey de Portugal, ni tampoco tocando en la conquista que se ha asseñalado al Comendador Miguel de Herrera, ni á otras personas; si hallaren é descubrieren algunas islas ó tierra de más de lo contenido y especificado en el dicho capítulo primero, que los dichos Fúcares lo puedan conquistar é poblar y se entienda ser de su conquista, segun y de la manera y con las mismas condiciones y gracias que lo demás que se les ha concedido, porque Magallanes descubrió algunas islas, pero ni las conquistó, ni pobló él, ni otro ninguno, y los dichos Fúcares esperan

\footnotetext{
${ }^{40}$ Medina (1889, vol. III) e Panhorst (1928: 278-287).
} 
descubrir mas islas é tierras en los dichos limites... Suplican a V. M. mande que las tales islas é tierras entren y se entiendan ser de su conquista, con las condiciones susodichas, pues V. M. será servido Y ellos han de gastar y aventurar su hacienda en el descubrimiento y conquista de las dichas tierras" ${ }^{41}$.

Vê-se, portanto, a importância que os Fugger davam às ilhas. Desistiram, quando perceberam que seu projeto quanto às ilhas era irrealizável. Notícias sobre as atividades dos conquistadores Pizarro e Almagro não teriam influído para o abandono de seus planos? O fato é que apesar de terem realizado estudos minuciosos sobre o projeto de colonização, não se lançaram à aventura. A região que devia ser colonizada pelos Fugger foi depois conquistada por Almagro.

A partir de 1525 o ramo dos Welser estabelecido em Nuremberg manteve relações com os países do Prata. Jakob Welser participou da expedição de Pedro de Mendonça ao Prata. Um dos navios pertenceu a Jakob Welser e Sebastian Neithart e era comandado por Heinrich Paine. Vieram na frota 150 alemães e flamengos entre os quais deve ser destacado Ulrich Schmidel, famoso aventureiro que depois narrou suas façanhas no continente Sul americano. A expedição chegou ao estuário do Prata em fevereiro de 1536; os acontecimentos que redundaram no fracasso completo da tentativa são por demais conhecidos. Panhorst (11928: 183), que contribuiu muito para o conhecimento das relações entre os banqueiros alemães e a América, fracassou, entretanto, inteiramente na interpretação da participação dos Welser na expedição ao Prata. Dá à viagem de Mendonça e dos alemães um certo cunho comercial, afirmando que trouxeram mercadorias para a região e que os navios certamente voltaram carregados. Que mercadorias levaram de volta, se a região não oferecia nem ao menos o necessário para a manutenção dos colonos e aventureiros que vieram com Mendonça? Sabe-se que dos 2.500 colonos só um quinto conseguiu sobreviver à miséria e aos ataques dos índios.

\footnotetext{
${ }^{41}$ Medina (1889, vol. III).
} 
Interessante é notar que Ulrich Schmidel que percorreu vastas extensões da América do Sul, narra que recebeu em Assunção ou nos arredores, em julho de 1552, uma carta do Faktor der Fuckrer de Sevilha, pedindo que voltasse para a Alemanha. Atrás dessa simples afirmação há algo de mais importante? Os Fugger tiveram algum interesse na região do Prata e do atual Paraguai? ${ }^{42}$

A tentativa de colonização da Venezuela e de explorá-la economicamente constituiu o empreendimento mais importante dos banqueiros alemães no que diz respeito aos negócios coloniais. Mostra o espírito aventureiro e empreendedor dos Welser. Pelas idéias que nortearam a tentativa, percebe-se que estavam firmemente dispostos a lançar as sementes para uma grande empresa, a qual poderia ter dado a essa casa bancária do sul da Alemenha um lugar de destaque na história das explorações e da colonização da América Latina. A participação dos Welser mostra "a grandiosa conexão íntima das nações que constituem o domínio de Carlos V" (Brandi 1943: 282). Não devemos, entretanto, esquecer que é uma empresa de uma firma particular e, portanto, "pode-se bem falar de uma colônia dos Welser na Venezuela, em compensação não é muito acertado falar-se de uma colônia alemã" (Haebler 1903: 405).

A tentativa redundou num grande fracasso, em parte devido aos próprios colonizadores, em parte às hostilidades dos espanhóis para com todos os estrangeiros que estivessem ligados aos negócios coloniais. Os inúmeros documentos que existem sobre essa empresa dos Welser, mostram que ela interessou vivamente os contemporâneos. Alguns escritores, como Bartolomeu de las Casas, só emitiram juízos pejorativos, procurando por em evidência unicamente as falhas dos primeiros coloniza-

\footnotetext{
${ }^{42}$ Schmidel ([1535-1554] 1926: 132). Este autor não precisa o lugar onde recebeu a carta mas deve ser ou em Assunção ou nos arredores. Diz Schmidel: "Na mesma época chegou para mim uma carta de Sevilha na Espanha do feitor dos Fugger que se chama Crestoff Reyser. Ao mesmo, Sebastian Neithart a pedido de meu defunto irmão Thoma Schmidel escreveu, se não era possível ajudaremme para voltar para casa. Essa mensagem o dito Criestoff enviou com muita diligência e solicitude, que recebi a carta no ano de 1552, no dia 25 de julho ou dia de São Jacó.”
} 
dores e exploradores da Venezuela dos Welser; outros, como Juan de Castellanos, não se cansaram de louvar o empreendimento. Apesar de já existirem estudos mais ou menos profundos sobre a colonização dos Welser na Venezuela, há ainda outros pontos obscuros. Os autores em geral se limitaram a examinar as diversas expedições exploradoras, deixando de lado o estudo da organização administrativa e econômica.

O documento de concessão da Venezuela foi firmado em Madri a 27 de março de 1528:

"El Rey: Por cuanto Enrique Einguere e Geronimo Sayller, alemanes, nuestros vasallos, me hiciesteis relación que vosotros estais informados que Nos mandamos a Garcia de Lerma vaya por nuestro gobernador a la provencia de Santamarta, y porque vosotros teneis noticias de aquella tierra y su comarca, y sabeis que los indios naturalles della son belicosos y flecheros, y una parte de ellos están rebelados, juntamente con ciertos cristianos y otras gentes que fueron en la muerte del gobernado Bastidas; e para pacificar la dicha tierra y reducirla a nuestro servicio de manera que se haya el provecho que de ella se espera, hay necessidad que el dicho Diego Garcia Lerma vaya muy acompañado y en orden de gente, armas y municiones y bastimentos, y de tal manera proveido que pueda allanar y pacificar la dicha tierra y poblarla y castigar los rebeldes y culpantes en el dicho levantamiento e muerte para lo qual es menester grandes gastos y dineros: y porque la empresa y poblacion de la dicha tierra nos yerre y ni aventure ni dilate vosotros os ofreceis de hacer una armada de cuatre navios o mas, com doscientos hombres o mas, armados e avituallados por un año, con los cuales el dicho gobernador allanará la dicha tierra de Santamarta; y asi mismo me hiciestes relación que junte a la dicha tierra de Santamarta y en la misma costa está otra tierra que es del Cabo de la Vela y Golfo de Venezuela y el Cabo de Sant Roman y otras tierras hasta el Cabo de Maracapana que están en la misma conquista, en que se incluyen muchas tierras y provincias, la qual tierra con la de Santamarta vosotros os ofreceis a pacificar y poblar de los dichos hombres y más otros ciento, que seran trescientos por todos, muy bien proveidos y armados, como dicho es, todo a vuestra costa e munición, sin que en ningún tiempo seanos obligados a vos pagar ni a satisfacer los gastos que en ello ficiederes, mas de lo que en esta capitulación vos será otorgado, y me suplicastes y pedistes por merced vos hiziese merced de la dicha conquista y población de las dichas tierras, e vos hiziese y otorgase las mercedes y con las condiciones que de yuso serán contenidas, sobre lo cual. Yo mande tomar con vosotros el asiento y capitulacion siguiente: 
Primeramente, cumpliendo vos lo que de suso os ofreceis, de ir o embiar la dicha armada con el dicho nuestro Gobernador de Santamarta e pacificando aquella como dicho es, vos doy licencia y facultad para que vos o cualquier de vos, y en defecto de cualquier de vosotros Ambrosio Alfinger o Jorge Einguer, hermanos de vos el dicho Enrique, o cualquier de ellos, podais descobrir y conquistar y poblar las dichas tierras y provincias que hay en la dicha costa, que comienza desde el Gabo de la Vela, o del fin de los limites y terminos de la dicha Gobernación de Santamarta, hasta, Maracapana, leste oeste, norte sur, de la una mar a la otra, contodas la sislas que están en la dicha costa, exceptuadas las que están encomendadas y tiene a su cargo el Factor Joan de Ampies, con tanto que seais obligados de llevar, y lleveis, destos nuestros Reinos o de fuera de ellos y de las personas que no estan prohibidas para ir a aquellas partes, a hacer la dicha población y hacer en las dichas tierras dos pueblos o más, los que a vosotros pareciere y en los lugares que vivredes que conviene; y que para cada una de elas dichas poblaciones lleveis a lo menos trescientos hombres, y hagais en la dicha tierra tres fortalezas, todo lo que dicho es a vuestra costa y municion; y seais obligados a partir de Espana, con los dichos trescientos hombres, el primero viaje dentro de un año de la fecha de esta capitulacion, y seais obligados a hacer los dichos dós pueblos dentro de dos años despues de llegados, y para todo esto deis la seguridád bastante que vos será señalada.

Outro si: que demas de los dichos trescientos hombres seais obligados a pasar a las islas Espanola, sant Juan y Cuba y a la dicha vuestra tierra y a otras cualesquier partes de las nuestras Indias y tierra firme e a las islas nuestras, dentro del dicho termino de los dichos dos años cincuenta alemanes naturales de Alemanis, maestros mineros a vuestra costa, Para que con su industria y saber se hallen las minas y veneros del oro plata y otros metales que oviere en las tierras e islas, e los repartir por ellas como a vosotros pareciere ques mas provecho nuestro; y que en el buen tratamiento, libertad y execución que han de tener los dichos alemanes, se guarde lo mismo que están otorgado y concedido a los mineros alemanes que residen en Galicia, en los mineros de aquel reino.

$\mathrm{Y}$ acatando vuestras personas y servicios y la voluntad con que os moveis a hacer lo suso dicho, es vuestra merced y voluntad de vos hacer merced, como por la presente vos la hago, para quel que de vosotros fuere a hacer la dicha conquista y población, todos los dias de vuestra vida seais nuestro Gobernador y Capitan general de la dicha tierra que ansi descubrieredes y poblardes, con salario en ca la vn por nuestro Gobernador de doscientos mill maravedis, y por Capitan General cien mil maravedis, y dello vos mandare dar nuestras cartas y provisiones y si por acaso vos, los dichos Einguer e Geronimo Sayller, no fuerdes en persona a lo suso 
dicho y embiardes a cualquiera de los dichos Ambrosio de Alfinger o Jorge de Einguer a las dichas conquistas y poblacion, teniendo poder y nombramiento vuestro para ello, cualquier de los que ansi nombraesstenga e use los dichos titulos de Gobernador y Capitan General el tiempo que vosotros quisieredes y por bien tuvieredes, no estando ninguno de vosotros en la dicha tierra.

Ansi mismo vos hare merced, como por la presente vos la hago, del oficio de mestre Alguacil mayor de las tierras, por vos y para vuestro heredero y sucessores, para siempre jamás, sin que por ello vos sea dado salario alguno más de los derechos pertencientes al oficio.

Ansi mismo vos hare merced, como por la presente vos la hago, de las tenencias de las dichas tres fortalezas que a vuestra costa os obligais a hacer e hicierdes vosotros en las dichas tierras; por los dias de vuestras vidas, y de vuestros herederos para siempre jamás, quales vosotros senalardes y quisierdes, con setenta y cinco mil maravedis de salario en cada año con cada una de ellas, y dello vos mandare dar provisión patente con tanto que las dichas fortalezas se hagan, si pareciere a vos y a los dichos nuestros oficiales de la dicha tierra que hay necessidad de ellas, y que sean tales quales vengan, a vista de los dichos oficiales. Otro si: acatando vuestras personas y servicios y lo que en la dicha población habeis de gastar, es mi merced y voluntad de vos hacer merced, como por la presente vos la hage, del titulo y oficio de nuestro adelantado de las dichas tierras al uno de vosotros los dichos Enrique Einguer y Geronimo Sayller, qual entre vosotros fuere concertado, para que aquel y sus herederos y sucessores para siempre jamás, sea nuestro Adelantado de las dichas tierras y islas, y dello vos mandase dar titulo y provision en forma.

Ansi mismo, acatando la voluntad con que os moveis a nos servir en lo suso dicho y el gasto que se os ofrece en ello; Quiero, y es mi voluntad, que en todas las tierras que asi descubrieredes y poblardes a vuestra costa, segun y de la forma y manera a que de suso se contiene, ayais y lleveis cuatro por ciento de todo el provecho que en cualquier manera se nos reiquiere, para vosotros y para vuestros herederos y sucessores para siempre jamás, sacando las costas y gastos que por nuestra parte fueren hechos y se hicieren en conservación y población de la dicha tierra en cualquier manera y los salarios que mandaremos pagar, asi a vosotros como a otras cualquier personas y oficiales nuestros y que para la dicha tierra en cualquier manera se proveyeren: pero no se entiende que habeis de llevar parte de las alcabalas ni almojarifazgo, ni penas de Camara, porque esto no es fruto de la tierra y ha de quedar enteramente para Nos.

Item: para vos hacer merced, es mi merced y voluntad, que de los mantemientos destos Reynos que llevardes a las dichas tierras, no pagueis derechos de almoja- 
ritazgo ni otros derechos algunos por todos los dias de vuestra vida, no siendo para vender, contratar ni mercadear con ellos; pero si despues de llevados los vendieredes, que despues que seais obligados a pagar los derechos de almojarifazgo.

Otro si: vos hago merced de doce leguas de quadra, de las que ansi descubrieredes, para que tengais tierra con que grangear e labrar, no siendo en lo mejor ni peor, esto a vista de vos y de los nuestros oficiales que para la dicha tierra mandaremos proveer, para que sea vuestra propria y de vuestros herederos y sucessores para siempre jamás, sin juridicion civil ni criminal, ni otra cosa que a nos pertencezca como a Reyes y Senores por razon de la suprema.

$\mathrm{Y}$ ansi mismo que vos dare licencia, como por la presente vos la doy, para que las nuestras islas Espanola, San Juan e Cuba y Santiago, podais llevar a la dicha tierra caballos e yeguas o otros ganados que quisieredes y por bien tuvieredes, sin que en ellos vos sea puesto embargo ni impedimiento alguno.

Y porque nuestro principal deseo o intencion es que la dicha tierra se pueble de cristianos, porque en ella se siembre y acresciente nuestra fé católica, y las gentes de aquellas partes seam atraidos convertidos a ella; digo, que por questo haya más cumplido y breve afeto a los vecinos que con vos, en este primero viaje o despues, a la dicha tierra fueren a la poblar, es mi merced de les hacer los mercedes siguientes: Que los tres primeros años de la dicha población, no se pague en la dicha tierra a Nos, del oro de mina solamente mas del diezmo, y el quinto año el noveno y de ay venga avajando por este orden hasta quedar en el quinto; y que de lo restante que se oviere, asi se rescate como en otra cualquier manera, se nos pague el dicho nuestro quinto enteramente, pero entiendase que los rescates y servicios y otros provechos de la tierra, desde luego havemos de llevar nuestro quinto como en las otras partes: Otro si: que a los primeros pobladores y conquistadores se les den sus vecindades y dos caballerias de tierras y dos solares y que cumplan la dicha vecindad en cuatro años que están y vivan en la dicha tierra, y aquellos cumplidos lo quedan vender y hacer dello como de cosa suya.

Otro si: que los dichos vecinos que fueren a la dicha tierra el dicho primer viage y despues ocho anos luego siguientes, no pagen derechos de almojarifazgo de los mantenimientos y provisiones que llevaren para su casa.

Otro si: por hacer merced a vos y a las dichas gentes que a la dicha tierra fueron, mando que por tiempo de los dichos ocho años no sean obligados a no pagar cosa alguna de la sal que comieran y gastaren, de la que en las dichas tierras oviere. Otro si: vos doy licencia y facultad a vos y a los dichos pobladores para que a los indios que fueron rebeldes, siendo amonestados y requeridos, los podais tomar por esclavos, guardando cerca destos lo que de yuso en esta nuestra capitulación y asiento sera contenido, y las otras instrucciones y provisiones 
nuestras que cerca dello mandaremos dar; desta manera e guardando la dicha orden, los indios que tuvieron o caciques y otras personas de la tierra por esclavos, pagandose los a su voluntad a vista de la justicia y beedores, y de los religiosos que con vos iran los podais tomar y comprar, siendo verdadeiramente esclavos, pagandonos el quito de los dichos esclavos.

Otro si, digo, que porque la dicha tierra mejor y mas brevemente se pueble mandare hacer a las dichas tierras las mercedes que tenemos hechas y tienen las otras tierras e islas que agora estan pobladas, siendo convinientes a la dicha tierra y no contrarias, las quales luego seais obigados a declarar, para provéer en ello. Otro si: que por tiempo de seis años vos mandare dar lugar en las nuestras atarazanas de Sevilla, en que tengais las cosas que se oviere de llevar y cargar para la dicha tierra, e vos dare licencia para que en las islas de Tenerife podais cortar cienypinos de los que alli tenemos nuéstros pudiendo se dar sin perjuicio de tercero, para que hagais de ellos lo que quisierdes.

Y que Nos siendo informados de los males y desordens que en descubrimientos y poblaciones nuevas se han hecho y hacen, y para que Nos con buena conciencia podamos dar licencia para lo poder hacer, para remédio de lo qual con acuerdo de lo nuestro Consejo y consulta nuestra, está ordenada y despachada una proposición general de capitulos sobre lo que habeis de guardar en la dicha poblacion y descubrimiento, la qual aqui mandamos encorporar, en tenor de la qual es este que se sigue, que va en todas las capitulaciones adelante.

Por ende, por la presente, haciendo vosotros lo suso dicho a vuestra costa y segun y de la manera que de suso se contiene, y guardando y cumpliendo lo contenido en ta dicha provision que de suso vá encorporada en todas las otras instrucciones que adelante vos mandaremos dar, guardar e hacer para la dicha tierra e para el buen tratamiento y conversión a nuestra Santa Fé Católica de los naturales della, digo y prometo que vos será guardada esta capitulación y todo lo que en ella contenido, en todo y por todo, según que de suso se contiene, e no lo haciendo ni cumpliendo asi, Nos no seamos obligados a vos mandar guardar e cumplir lo susodicho ni cosa alguna dello, antes vos mandaremos castigar y transproceder contra vosotros, como contra persona que no guarda y cumple y pasalos mandamientos de su, Rey y Senor natural [...]"

\footnotetext{
${ }^{43}$ Panhorst (1928: 194-7). O documento se encontra no Archivo General de Indias I-1; 1/27.
} 
Os problemas já começam na verificação de que nesse documento não há a mínima referência aos Welser. A região foi concedida a Enrique Einguere (Heinrich Ehinger) e a Jerônimo Sayller (Hieronymus Sailer), os quais podiam ser substituídos na conquista por Ambrósio Alfinger (Ambrósio Ehinger) ou Jorge Einguer (Georg Ehinger), irmãos de Heinrich Ehinger. Haebler (1897: 181) está propenso a acreditar que realmente no início os Welser não estavam ligados a essa empresa e que a passagem dos direitos aos Welser só foi confirmada pelo Conselho das Índias a 17 de fevereiro de 1531. Entretanto, segundo Panhorst (1928: 97), "quase todos os Ehinger, que trabalharam na primeira metade do século XVI na Espanha e na América, agiam sob as ordens da grande casa augsburguense de comércio dos Welser. Eles eram os representantes e em parte os sócios dos Welser".

Sendo assim, podemos concluir com Panhorst que também no caso da doação da Venezuela, Heinrich Ehinger tivesse agido apenas como representante e sócio dos Welser. Herrera por duas vezes mostra que os Welser eram realmente os donos da Venezuela. “... Enrique Alfinger, i Geronimo Sayller, Alemanes, en nombre de los Belçares, sus principales", sabendo da existência de uma terra muito rica vizinha à província de Santa Marta, ofereceram-se ao rei para conquistar essa terra (Herrera 1726: 70). Um pouco mais adiante esse cronista, falando da primeira expedição à Venezuela e da expulsão de Juan de Ampies (ou Ampues), diz que esse Ampies nada pôde fazer para não ser expulso, pois "los Belçares Alemanes, que eran los principales a quien se havia dado esta Gobernacion eran poderosos, i socorriam al Emperador" (Herrera 1726: 101).

Os Ehinger foram os inspiradores dos Welser quanto a essa empresa. Agindo na Espanha, conhecendo os pormenores da empresa colonial espanhola, e estando um membro da família - Ambrósio Ehinger - em São Domingos à testa da feitoria dos Welser, os Ehinger não podiam deixar de se interessar por uma empresa desse tipo, ainda mais tendo o apoio da imensa força financeira dos Welser. O interessante é que a maioria dos autores discute o problema da concessão da região a Ehinger e Sailer e do silêncio sobre a participação dos Welser, sem, entretanto, se terem preocupado em examinar mais profundamente o documento sobre a passagem dos direitos para os Welser. O próprio Panhorst que em sua obra transcreveu o documento 
de 17 de fevereiro de 1531 não se valeu dele para comprovar sua afirmação de que Ehinger e Sailer agiram em nome dos Welser ${ }^{44}$. Esse documento mostra claramente as verdadeiras condições do primitivo asiento de 1528. Esse asiento como todos os outros que tinham sido feitos em nome de Heinrich Ehinger e Hieronymus Sailer, "avian sido en nombre de vos bartolome belzer e Antonio Belzer"

Carlos V dirigiu-se a 20 de novembro de 1530 ao Conselho das Índias para que ratificassem a exclusão de Heinrich Ehinger e de Hieronymus Sailer da empresa de colonização da Venezuela, e a passagem dos direitos aos Welser. A ratificação foi dada pelo Conselho das Índias a 17 de fevereiro de 1531.

A causa dessa concessão aos Welser não é muito bem conhecida. Para Merriman, como já foi dito, Carlos V vendo que a colonização na América ia de mal a pior tanto econômica como humanitariamente, resolveu aproveitar os Welser para essa tarefa. Talvez as notícias do famoso Eldorado tivessem despertado a atenção desses banqueiros de Carlos V. Parece que foi Bartolomeu de las Casas que espalhou a notícia errada das toneladas de ouro com as quais os Welser teriam comprado a Venezuela. E durante muito tempo isso foi levado a sério... Entretanto, Panhorst (1928: 98) chega mesmo a afirmar que a concessão da Venezuela não se prende a nenhum problema financeiro do imperador. Certamente a doação da Venezuela é devida aos pedidos da feitoria de São Domingos. Sentiram necessidade de uma base territorial para suas atividades comerciais. Haebler (1903: 59) apresenta uma tese muito audaciosa: “...o comércio de escravos negros [a partir de São Domingos] levou-os a se aproximarem do comércio de escravos índios, e êsse deu margem a se apoderarem da Venezuela".

Os Welser souberam aproveitar-se muito bem das circunstâncias para conseguirem a doação da região "desde el Cabo de la Vela, o del fin de los limites

\footnotetext{
${ }^{44}$ Panhorst (1928: 97); para comprovar sua tese este autor cita um documento do Archivo General de Indias (49 -6 ;22/25), onde o governador da província vizinha declara que a nomeação de Ambrósio Ehinger para governador da Venezuela, como também as outras condições do tratado só foram ratificadas depois do consentimento dos Welser.

${ }^{45}$ Panhorst (1928: 206-7); o documento se encontra no Archivo General de Indias, 1. 1. - 1/27. Haebler (1903: 181) contesta a veracidade da afirmação desse documento.
} 
y terminos de la dicha Gobernacion de Santamarta, hasta Maracapana, leste oeste, norte sur, de la una mar a la otra...". Sabiam que "los indios naturales della son belicosos y flecheros, y una parte de ellos están rebelados, juntamente con ciertos cristianos y otras-gentes"; argumentavam então que o governador enviado para a província de Santa Marta devia ir "muy acompañado y en orden de gente, armas y municiones y bastimentos"... para "pacificar la dicha tierra y poblarla y castigar los rebeldes". Os Welser, ou melhor, seus plenipotenciários Heinrich Ehinger e Hieronymus Sailer, se ofereceram para "hacer una armada de cuatre navios o mas, con doscientos hombres o mas" para ajudar o governador Garcia de Lerma de Santa Marta e ao mesmo tempo insinuavam que próximo a essa província havia uma região, "la cual tierra con la de Santamarta" se ofereciam " a pacificar y poblar de los dichos hombres y más otros ciento" ".

Antes da assinatura do acordo sobre a Venezuela, os dois representantes dos Welser fizeram um tratado particular com Garcia de Lerma em Burgos a 4 de fevereiro de 1528. As forças deveriam primeiramente seguir Garcia de Lerma e depois parte das mesmas deveria ficar durante um ano com Lerma (Habler 1903: 91). Em outubro de 1528 partiu de San Lucar a primeira frota dos Welser; eram dois navios e duas caravelas com 281 homens ${ }^{47}$. Garcia de Lerma comandante dessa frota passou por São Domingos, a partir de onde Ambrósio Ehinger passou a ser o comandante da expedição. Verificando-se que o governador de Santa Marta não tinha mais necessidade de auxílio, Ambrósio Ehinger dirigiu-se para Santana de Coro, onde desembarcou a 24 de fevereiro de 1529. Santana da Coro havia sido fundada por

\footnotetext{
${ }^{46}$ Carta de doação da Venezuela.

${ }^{47}$ A partir da organização da frota, é possível ter certeza de que se trata de um empreendimento dos Welser, por meio das crônicas se sabe que os recrutadores de marinheiros faziam propaganda para a "frota dos Welser".
} 
Juan de Ampies em 1527. Ampies tinha recebido a permissão de proteger os índios e recolonizar certas ilhas e a Venezuela. Em novembro de 1527 recebeu o monopólio de pau brasil, mas, como veremos mais tarde, parece que além desse comércio mantinha também um tráfico bastante ativo de escravos índios. Ampies, portanto, "huvola de dexar.. aunque tenia buena parte de ella pacifica i por mucho que procuró el remedio no le pudo alcançar; porque los Belçares Alemanes, que eran los principales, a quien se havia dado esta Gobernacion eran poderosos, i socorrian al Emperador" (Herrera 1726: 101).

Coro transformou-se no centro mais importante da Venezuela dos Welser, daí partiram todas as expedições para o interior. Era o porto mais importante, a sede administrativa, o primeiro núcleo urbano. No início os Welser e seus representantes tinham interesse em colonizar a região que lhes fôra concedida, além de explorá-la economicamente, aproveitar o indígena como escravo e realizar pesquisas sobre a existência de metais preciosos. Cedo, entretanto, abandonaram quase por completo o trabalho de colonização. O ouro, as pedras preciosas e os escravos indígenas fascinavam os primeiros colonos de tal maneira que abandonaram a agricultura e a vida sedentária. A história da Venezuela dos Welser se resume em expedições e mais expedições para o interior... Imaginavam encontrar o famoso Eldorado. Os heróis dessa penetração para o interior não deixaram nada a dever aos maiores conquistadores espanhóis e portugueses em matéria de crueldade, desonestidade e falta de escrúpulos. Vamos fazer apenas um rápido esboço das expedições para o interior e dos acontecimentos políticos mais importantes. É uma história cheia de fracassos e crueldades. Os pormenores dessas expedições são pouco conhecidos e não raro os cronistas confundiram uma expedição com outra, daí a dificuldade em se atinar com a verdade.

O primeiro governador da Venezuela, Ambrósio Ehinger, o "Alfinger" ou "Dalfinger" das crônicas espanholas, empreendeu três expedições. A primeira foi apenas de orientação, as outras duas de exploração. A primeira expedição deu origem ao povoado de Maracaibo (Panhorst 1928: 202). Na segunda entrada procurou conhecer melhor as margens do mar de Maracaibo, a península de Guajira e o Cabo de la Vela. Panhorst afirma que não se pode provar que tenha atravessado o rio Madalena e fundado 
outro povoado, Tamalameque. Parece que encontrou um pouco de ouro. Ambrósio Ehinger, entretanto, teve que voltar para Coro devido às desordens entre os colonos daquela localidade. Tinha chegado a Paraguana um navio com 123 colonos e 24 mineiros alemães sob a chefia de Georg Ehinger que não encontrando notícias de seu irmão, tornou-se o governador, como estipulava o asiento de 1528 (Panhorst 1928: 205). Os colonos, entretanto, não o aceitaram e devido à rebelião foi obrigado a retirarse. Em março de 1530 Nikolaus Federmann trouxe mais colonos de São Domingos e em abril chegaram a Coro mais três navios dos Welser com colonos sob a chefia de Hans Seissenhofer. Como ainda não tivessem notícias sobre o paradeiro de Ambrósio Ehinger e como se apresentasse calmamente, deixaram que se tornasse o governador da Venezuela (Habler 1903: 173). Ambrósio Ehinger voltando seguiu imediatamente para São Domingos para tratar de seus interesses. Não querendo se afastar do serviço dos Welser como seu irmão Heinrich Ehinger na Espanha, foi reposto como governador da Venezuela. Voltando, Ambrósio Ehinger organizou nova expedição, expedição essa que forneceu a Federmann os fundamentos para suas grandes incursões. Nas proximidades do rio Madalena, em meados de 1533 o governador foi morto por uma flecha envenenada. Durante a ausência de Ambrósio Ehinger houve em Coro diversas desordens, quase sempre devidas aos conflitos com os índios. Os conflitos entre os colonos aumentaram quando chegou a notícia da morte do governador. A Audiência de São Domingos, a pedido da feitoria dos Welser, nomeou como governador provisório o bispo Bastidas. Por um momento os Welser pensaram em nomear Federmann, mas devido às queixas dos colonos contra esse aventureiro, ele foi nomeado apenas para capitão general e como governador foi designado em janeiro de 1535 o feitor dos Welser em Sevilha, Georg Hohermut, natural de Espira (Panhorst 1928: 219). Viajou para a Venezuela com três navios e em companhia de Federmann (que tinha ido para a Europa) e de 600 homens. Imediatamente Hohermut organizou uma expedição para o interior. Percorreu áreas extensas, sendo mesmo provável que tenha chegado até a bacia do Amazonas. Parece que encontrou indícios de existência de ouro, conseguindo levar a Coro 8.000 pesos desse metal precioso. Devido às 
inúmeras dificuldades encontradas e às privações, dos 400 expedicionários só voltaram a Coro cerca de cem ${ }^{48}$.

O conquistador por excelência, o herói da penetração alemã na Venezuela, foi Nikolaus Federmann, natural de Ulm. Um aventureiro perfeito, enérgico e sem escrúpulos. Quando um funcionário real lhe era molesto, afastava-o simplesmente. São famosas suas crueldades, principalmente com os índios. Escreveu suas aventuras, fanfarreando aos quatro ventos suas proezas. Só depois da publicação das Elegias de varones ilustres de Juan de Castellanos, verificou-se que não se podia dar crédito às afirmações de Federmann.

Já em 1530 fizera uma expedição sem a autorização do governador. Em seguida, esteve na Europa onde impressionou os Welser com seus relatos. Voltando para a América com Hohermut ficou combinado que iria primeiro fundar um fortim no Cabo de la Vela e que depois seguiria George Spira, como Hohermut é chamado nas crônicas espanholas. Federmann, entretanto, tudo fêz para evitar um encontro com Hohermut, pois esperava sua nomeação para governador e era por demais ambicioso para obedecer às ordens de quem quer que fôsse. Assim, em vez de seguir as ordens, foi para São Domingos onde esperava encontrar sua nomeação e onde se preparou para sua ambicionada expedição para o planalto em que supunha encontrar grande abundância de ouro. Como o governador de Santa Marta ficasse conhecendo seus planos, Federmann resolveu partir para o planalto imediatamente, pois não tinha certeza se o almejado planalto de Bogotá por direito pertencia à Venezuela ou a Santa Marta ${ }^{49}$. Transpôs, através de muitas dificuldades, a Cordilheira e em fins de 1538 atingiu o planalto de Bogotá (Panhorst 1928: 212). Qual não teria sido sua decepção ao verificar que os colonos de Santa Marta avançaram muito mais depressa e que Quesada estava lá há algum tempo. Depois de algumas discussões, Federmann e Quesada, os dois

\footnotetext{
${ }^{48}$ A principal fonte para essa expedição é o relato de Philip von Hutten, Zeitung aus Indien Junkherr Philips von Hutten.

${ }^{49} \mathrm{O}$ governador de Santa Marta e Federmann tiveram notícias dessa região por meio das explorações de Ambrósio Ehinger.
} 
descobridores do planalto de Bogotá, chegaram a um acordo e, segundo Juan de Castelhanos, "hicieran un corpo de su gente" (apud Panhorst 1928: 234). Logo após a chegada de Federmann a região de Bogotá foi "descoberta" pela terceira vez por Benalcazar vindo do Peru. Os três conquistadores resolveram deixar a decisão sobre a posse dessa região a cargo do imperador. Para isso dirigiram-se à Espanha. Mas antes organizaram um povoado próximo a uma aldeia de índios: Santa Fé de Bogotá. A administração coube ao pessoal de Quesada e como pároco foi designado o dos Welser. Quesada ainda concedeu a Federmann a atual região de Tunja. Os três conquistadores Quesada, Federmann e Benalcazar tinham encontrado a tão procurada região dos chibchas, mas ficaram decepcionados, pois não encontraram tantas riquezas como imaginaram. O ouro que encontraram foi dividido entre os três. Federmann, chegando a Europa foi processado pelos Welser por causa de acusações vindas da Venezuela e de São Domingos. Esse homem ambicioso não pôde empreender mais nenhum de seus gigantescos planos, pois foi preso e logo faleceu. Os Welser reclamaram a região de Tunja; mas não tinham provas concretas, pois os exploradores alemães Ambrósio Ehinger e Federmann estavam mortos...

O período desde a partida das expedições de Hohermut e Federmann até o assassínio de Bartolomeu Welser e Phillip von Hutten no interior da província, foi dos mais infelizes para os Welser. Como não se tivesse notícias sobre o paradeiro do governador Hohermut, a Audiência de São Domingos deu a Antônio Navarro o poder de comissário real e de juiz. Não sendo bem recebido pelos colonos, o bispo Bastidas foi enviado novamente para a Venezuela (Habler 1903: 280-297). Hohermut voltou de suas explorações; imediatamente preparou outra expedição, mas faleceu antes de partir. Hutten foi indicado para chefiar a expedição, da qual fêz parte Bartolomeu Welser, um jovem da família proprietária da província. Fôra enviado para a América não se sabe muito bem se para preparar-se para ser o futuro governador da província. O itinerário dessa expedição não é muito bem conhecido. A finalidade dessa entrada era verificar a veracidade das notícias sobre as riquezas dos omaguas. Parece que atravessaram o divisor de águas entre a bacia do Orenoco e a do Amazonas. Em Coro a situação piorava e o bispo Bastidas se retirou da Venezuela. O fiscal Juan de Frias 
recebeu uma ordem da Audiência de São Domingos para fiscalizar, além de outras regiões, também a Venezuela, obtendo os direitos de governador. Como não pudesse partir imediatamente para lá, enviou a Coro como seu substituto Juan de Carvajal, um indivíduo de péssima reputação. Carvajal, usando de força, obrigou os colonos a penetrarem com ele para o interior, pois tinha recebido ordem de assegurar a região do Barquisimeto e do médio Tocuyo por meio da colonização. Sua finalidade, entretanto, parece que era despovoar Coro, para ter maior liberdade de ação no interior. Em dezembro de 1545 fundou a cidade de Tocuyo. Carvajal mandou assassinar Hutten e Bartolomeu Welser quando esses, em sua volta, atingiram Tocuyo. Com o assassínio de Hutten termina o período de explorações na Venezuela dos Welser. Quando se soube no Conselho das Índias do abandono de Coro por ordem de Carvajal, nomearam em setembro de 1545 um funcionário Juan Perez de Tolosa para resolver o problema da administração da Venezuela. Tolosa conseguiu implantar na Venezuela um regime de paz e de ordem, depois de ter condenado e executado Carvajal. Surgiram diversos povoados, a agricultura e o pastoreio se desenvolveram. Tolosa com suas atividades colonizadoras, quase esqueceu que devia mover um processo contra os Welser devido aos contínuos problemas de administração na Venezuela. A opinião pública estava a favor dos Welser devido ao assassínio de Hutten e Bartolomeu Welser, e Tolosa tendo visto os problemas coloniais de perto foi muito justo para com os Welser, que tinham investido grandes somas na província. Tolosa, entretanto, dirigiu por pouco tempo a colônia, pois faleceu em 1549. Antes de sua morte, nomeara Villegas seu substituto. Também Villegas seguiu a política colonizadora, impedindo a continuação das explorações do interior. Diego de Losada foi o último a dirigir a Venezuela dos Welser. A Venezuela progredia lenta, mas seguramente e quanto maior o progresso, tanto mais a coroa se interessava em reaver a colônia...

Os esforços despendidos para encontrar ouro foram em vão. Os alemães penetraram profundamente no interior da Venezuela - muitas regiões atravessadas pelos aventureiros alemães, só foram redescobertas no século passado - apenas não tiveram a sorte de um Cortez ou de um Pizarro. A região que coube aos alemães não ofereceu riquezas fáceis. A decepção foi grande, pois esperavam encontrar 
grandes riquezas fáceis. Tinham pedido a província porque era "una mui rica tierra, de la qual se podia sacar mucho provecho, porque en ella se havian descubierto muchas minas..." (Herrera 1726: 70).

Como já foi visto, no asiento sobre a concessão da Venezuela havia um item que fala de mineiros alemães que deviam ser levados ao Novo Mundo. Naturalmente, também a colônia dos Welser foi beneficiada com essa permissão; as diversas frotas que os Welser enviaram para a Venezuela transportaram também mineiros para lá. Sobre o destino desses mineiros tem-se, entretanto, poucas notícias. Devem ter tomado parte nas explorações do interior e muitos certamente não voltaram mais, falecendo devido às privações por que passaram. Em geral o ouro encontrado era de aluvião, e às vezes encontraram quantidades relativamente grandes. Na região dos chibchas esse metal tão cobiçado era um pouco mais abundante. Como se sabe, lá o ouro constituia a principal oferenda aos deuses. O rei-sacerdote em certa festa anual, era coberto com pó de ouro, e esse rito certamente deu origem à célebre lenda do Eldorado (Goetz 1932: 535). As diversas expedições encontraram indícios da existência de minas de ouro, mas a quantidade do metal precioso não permitia uma exploração intensiva. Próximo a Boca de los Llanos encontraram durante o governo de Villegas minas, as quais, apesar de não serem muito importantes, deram origem ao povoado de San Felipe de Buria (Habler 1903: 366). Essas minas fixaram os colonos, e o que é muito importante, impediram a continuação da emigração para as províncias vizinhas que desde a época de Carvajal vinha despovoando a Venezuela.

Os Welser deviam pagar nos três primeiros anos de colonização “del oro de mina solamente más del diezmo, y el quinto año el noveno y de ay venga avajando por este orden hasta quedar en el quinto" (Panhorst 1928: 194-7). Carlos V tinha dado a seu secretário Francisco de los Cobos o direito de fiscalizar a fundição de metal precioso no Novo Mundo, podendo cobrar um imposto de $1 \%$ de todo metal levado para a fundição. Cobos incumbiu Sailer e Heinrich Ehinger de representarem em Santa Marta e na Venezuela seus direitos. Francisco de Orduña, o agente dos Welser em Santa Marta, devia controlar lá a fundição dos metais preciosos. Essa concessão de Cobos deu aos Welser mais uma fonte de renda na Venezuela. 
Não foram só os metais preciosos que interessaram aos Welser, o sal também foi objeto de item especial no asiento sobre a Venezuela. O imperador mandou que durante 8 anos o sal encontrado na província e destinado ao consumo, fosse isento de impostos. Não temos, entretanto, notícias sobre a exploração do sal, mas parece que o porto de Burburata, fundado quase no fim do período dos Welser, teve grande vantagem sobre o de Coro, além de outros fatores devido a existência de salinas próximas, pois o sal era uma mercadoria muito procurada.

As pérolas também eram muito procuradas na Venezuela dos Welser e em outros pontos do mar das Caraibas. As costas da Venezuela atraiam navegantes por causa dos achados de pérolas (Babelon 1947: 92). Há notícias de que já em 1531 ou antes foram encontradas pérolas em Paraguaná. Parece tratar-se exclusivamente de achados isolados que naturalmente não proporcionavam grandes lucros (Haebler 1903: 131). Melhores perspectivas de lucro oferecia a região do Cabo de la Vela. Não se sabe quando foram encontradas aí as primeiras pérolas. Provavelmente a fixação do limite da colônia dos Welser nesse cabo se prenda a notícias da existência de bancos de pérolas. Em todo caso, já antes de 1536 devia haver uma certa exploração desses bancos, pois nessa data Federmann recebeu ordem para construir no cabo um fortim; o aventureiro, entretanto, preferiu partir para o planalto de Bogotá, dando como desculpa as pretensões de Santa Marta sobre a região do cabo. Como os bancos de pérolas do Mar das Antilhas já não produzissem mais tanto, os pescadores de pérolas começaram a intensificar a exploração no Cabo de la Vela. Em 1540 chegou a Coro um navio procedente de Cabo de la Vela, trazendo 230 marcos em pérolas como rendimento das primeiras tentativas. No fim de 1540 e começo de 1541 as pérolas deram um lucro de 1.500 pesos para os cofres dos funcionários da administração no Cabo de la Vela (Haebler 1903: 131-3). Cedo, entretanto, começaram as rivalidades entre Santa Marta e Venezuela, sendo que por direito a região dos bancos de pérolas pertencia a Santa Marta. Os colonos de Santa Marta apoderaram-se do povoado, pois os governadores da Venezuela não se tinham preocupado em fortificar a região, como havia sido ordenado. O governo espanhol interveio e proibiu aos governadores de Santa Marta e da Venezuela que interferissem no povoado do Cabo 
de la Vela. O povoado foi organizado num regime independente, subordinado ao governo central com o nome de Nuestra Senora Santissima Maria de los Remédios del Cabo de la Vela. Os colonos do povoado pertenceriam à diocese de Santa Marta e as apelações judiciárias também deviam ser dirigidas para aquela província. Percebe-se que Santa Marta foi favorecida, mas Tolosa conseguiu que a fiscalização dos bancos de pérolas ficasse para a Venezuela. O processo entre as duas províncias por causa dessa região durou muito tempo; parece que até o século XVII não tinha sido resolvido o problema da posse do Cabo de la Vela. De 1541 a 1543 a exploração das pérolas atingiu um valor de 150.000 pesos, recebendo a coroa um quinto (Haebler 1903: 136). Em 1560, entretanto, já aparecem queixas sobre os resultados muito fracos. (Nessa época os Welser já não estavam mais interessados na Venezuela). Parece que os Welser levaram escravos negros à Venezuela especialmente para a exploração de pérolas (Babelon 1947: 92). Os Welser certamente obtiveram certo lucro com os bancos de pérolas, apesar de todos os contratempos; ainda mais que o homem renascentista apreciava muito as pérolas, basta lembrar os colares de pérolas das pessoas retratadas por Tiziano ${ }^{50}$.

A maior parte dos colonos que vieram para a Venezuela era constituída por mercenários e quase todos os alemães que se destacaram na chefia das expedições tinha sido Landsknechtfuehrer em sua pátria (Goetz 1932: 535). Os alemães porém sempre constituíram uma minoria, a maior parte dos colonos era originária da Espanha. Há notícias de que nas frotas enviadas pelos Welser, também tinham vindo mulheres. Parece que Ampies trouxe as primeiras mulheres européias para a Venezuela (Haebler 1903: 163), e que com Ambrósio Ehinger também vieram

\footnotetext{
${ }^{50}$ Mesmo depois do abandono da Venezuela pelos Welser, as pérolas do Cabo de la Vela ainda interessavam aos antigos banqueiros de Carlos V; basta citar uma carta aos Fugger de 1582 que se refere as mercadorias chegadas da América e a "cueros perlas qui vienen de santo domingo y del Cavo de la Vela y hunduras". Fotocópia em poder do Instituto Hans Staden, São Paulo, do documento cod. 8955, fol. 405r na Oestreichische Nationalbibliothek, Viena
} 
algumas (Brandi 1943: 283). Alguns documentos, entretanto, afirmam expressamente que foi na frota de Seissenhofer que vieram as primeiras mulheres européias, inclusive algumas alemãs, pois alguns mineiros de Joachimstal vieram com as esposas (Panhorst 1928: 207). Isso é muito importante, pois é uma prova de que os Welser pretenderam, pelo menos no começo, empreender a colonização da Venezuela e não explorar simplesmente suas riquezas naturais. Além das grandes frotas que vinham da Europa, os Welser enviaram para a sua colônia nos anos de 1528 a 1540 cerca de 600 pessoas de São Domingos, Cubagua, San Juan e Cuba.

Apesar de grande parte dos colonos ter sucumbido durante as expedições, surgiram na colônia dos Welser alguns povoados. Santana de Coro, o primeiro núcleo, foi fundado por Ampies e tornou-se base das operações dos lugar-tenentes dos Welser. Era dirigida por dois burgomestres - os primeiros funcionários urbanos da Venezuela (Panhorst 1928: 202). O interessante é verificar que as fontes, principalmente os autos dos processos movidos por funcionários reais contra os Welser, diversas vezes se referem a uma assembléia de colonos reunida para resolver problemas graves. Era um órgão deliberativo? Era permanentemente organizado ou só funcionava esporadicamente? Os colonos reuniam-se simplesmente quando a situação do povoado se tornava angustiante? Diversas frotas trouxeram colonos para Coro, onde realmente se fixaram no começo para logo abandonarem a cidade para seguir as expedições para o interior. Houve épocas em que a cidade estava quase desabitada; assim, por exemplo, quando Federmann partiu para sua grande expedição, havia em Coro apenas 60 habitantes. Além das incursões para o interior, também a febre dizimava a população. Hohermut chegou mesmo a pensar em mudar o povoado para um lugar mais salubre e fértil; foi obrigado a desistir pois o número de colonos era insignificante e todos só pensavam fazer explorações e encontrar ricas jazidas de ouro (Haebler 1903: 278). Os Welser reconheceram a péssima situação de Coro e pouco a pouco se desinteressaram em manter lá uma grande filial e organizar um grande comércio com produtos venezuelanos. Em Coro só permaneceu um agente para cuidar dos interesses dos Welser, mas, apesar de tudo, o povoado continuou como a sede dos funcionários reais. $\mathrm{E}$, se as frotas não trouxessem sempre novos 
colonos, esse núcleo teria desaparecido fatalmente. Além de todas as dificuldades com as quais os habitantes de Coro lutavam, Carvajal conscientemente tudo fez para acabar com o povoado; tiranicamente obrigou os colonos a seguirem com ele para o interior. Por diversas vezes exigiu que todos os habitantes de Coro fossem com ele para o interior. A 7 de dezembro de 1545 fundou o povoado de Tocuyo. Recebera realmente uma ordem de assegurar por meio da colonização, a região do Barquisimeto e do médio Tocuyo como celeiro (Panhorst 1928: 253). Parece, entretanto, que quis com o abandono de Coro e, portanto, da costa, evitar a prestação de contas tanto aos Welser, como à administração espanhola por seus atos decorrentes de sua ambição desenfreada. Quando Tolosa chegou a Coro, esse povoado só contava com 70 habitantes. Carvajal quis arruinar Coro, fundando Tocuyo; não se sentiu, porém muito seguro lá e preparou sua retirada para terras de Nova Granada (Haebler 1903: 342). Para isso já tinha reunido um bom rebanho, pois sabia que em Nova Granada havia escassez de gado. Tolosa, entretanto, conseguiu impedir a retirada desse aventureiro, prendendo-o em Tocuyo. Encontrou em companhia de Carvajal 250 colonos e 18 mullheres que tinham reunido um grande rebanho de gado, cavalos, carneiros e porcos ${ }^{51}$. Esses colonos estavam dispostos a emigrar e Tolosa teve que despender grandes esforços para demovê-los de seu intento. Isso só conseguiu com a organização de uma entrada para o vale onde Ambrósio Ehinger fora morto por uma flechada. Os colonos mais experientes, cerca de 100, fizeram parte da expedição, o resto ficou em Tocuyo e Tolosa enviou alguns para Coro, a fim de impedir que esse povoado desaparecesse (Haebler 1903: 346).

Ambrósio Ehinger em sua primeira expedição fundou um povoado, Maracaibo, nas margens do mar de Maracaibo. A finalidade desse povoado era manter relações com os índios e devia funcionar principalmente como um centro de apresamento de índios e como base para as explorações para o oeste. Certamente deveria formar um ponto de

\footnotetext{
${ }^{51}$ Moses (1898: 165) afirma que em Tocuyo a população era de 59 habitantes, havendo dois alcaides e quatro corregedores. Segundo esse autor, foi o único estabelecimento municipal na Venezuela dos Welser.
} 
defesa da fronteira contra uma eventual incursão dos colonos de Santa Marta. Federmann, entretanto, dissolveu o povoado de Maracaibo antes de se dirigir para o planalto de Bogotá. Mas devido a sua situação, não desapareceu completamente. Não se tem notícias precisas se Ambrósio Ehinger realmente fundou outro povoado - Tamalameque.

Hutten antes de ser assassinado elaborara um plano colonizador. Queria fundar três povoados para garantir a posse da terra: um no interior que deveria funcionar como base de operações contra os omaguas, um no litoral onde houvesse um porto melhor que em Coro e, finalmente, um a meio caminho entre os dois primeiros para facilitar a comunicação entre ambos. Tolosa retomou o plano de Hutten e a 27 de fevereiro de 1548 foi festivamente inaugurada a Cidade de Nuestra Señora de Concepcion de Burburata, onde havia um melhor porto que em Coro e sua situação permitia que se pensasse em organizar rotas de comércio a partir da costa até Nova Granada e talvez até Quito. Além disso as salinas da região também tinham certa importância. Esse povoado prosperou bastante, pois para lá foi levado gado de Tocuyo (Haebler 1903: 349). No governo de Villegas, como já foi visto, a descoberta de minas de ouro fez surgir o povoado de San Felipe de Buria. Assim, durante os governos de Tolosa e de Villegas apareceram povoados duradouros que se dedicavam à agricultura e à criação de gado. O comércio de gado também foi um fator de prosperidade. Note-se que o povoamento teve sucesso durante a administração de homens que não contavam mais com o inteiro apoio dos Welser e esses banqueiros tinham que aceitá-los como governadores devido à imposição do governo espanhol. No asiento de 1528 lê-se que o "principal deseo e intencion es que la dicha tierra se pueble de cristianos, porque en ellas se siembre y acrescente nuestra santa fé católica, y las gentes de aquellas partes sean atraidos convertidos a ella".

Não há, entretanto, muitas notícias sobre a organização das missões na colônia dos Welser; os principais autores que estudaram a colonização alemã não se preocuparam com o assunto. Sabe-se apenas que a 1 de julho de 1532, a pedido dos Welser, Rodrigo de Bastidas foi nomeado bispo de Coro (Haebler 1903: 218). Por ocasião da morte de Ambrósio Ehinger, Bastidas foi nomeado governador e como tal procurou organizar os negócios espirituais, criando três missões e chamando sacerdotes para a Venezuela ${ }^{52}$. 
Os índios das costas da Venezuela eram muito procurados antes da concessão da região aos Welser pelos escravagistas das Antilhas. Juan de Ampies recebeu a permissão para proteger os índios e recolonizar certas ilhas e a Venezuela, onde constantemente apareciam os preadores. Em 1527 Ampies e um sócio receberam o monopólio do pau brasil. Haebler acha que Ampies praticava além do comércio com o pau brasil também o tráfico com escravos indígenas; para isso aliou-se aos aruaques que lhe forneciam como escravos índios de tribos inimigas, principalmente índios caraibas $^{53}$. A doação da Venezuela aos alemães, aos quais se permitia a escravização do índio, é uma prova de que Ampies na realidade não estava pacificando e protegendo os índios, pois no caso contrário seria absurdo a coroa conceder uma região em que se protegia os índios aos Welser, cujo interesse na escravização dos índios está provado pela própria carta de doação da região. Ambrósio Ehinger, feitor dos Welser em São Domingos, conhecia o comércio com índios escravizados e tendo conhecimento das negociações sobre o transporte de escravos negros, certamente chamou a atenção de seus superiores, mostrando que se podia auferir bons lucros com os escravos indígenas. Haebler está plenamente convencido de que os Welser se interessaram pela Venezuela com a finalidade de apresar índios. Na carta de concessão da Venezuela o imperador lhes deu:

"licencia y facultad a vos y a los dichos pobladores para que a los indios que fueron rebeldes, siendo amonestados y requeridos, los podais tomar por esclavos, guardando cerca destos lo quede yuso en esta nuestra capitulación y asiento sera contenido, y las otras instrucciones y provisiones nuestra que cerca dello mandaremos dar; desta manera e guardando la dicha orden los indios que tuvieron o caciques y otras personas de la tierra por esclavos, pagandose los a su voluntad a vista de la justicia y beedores,

\footnotetext{
52 Note-se que quando Federmann e Quesada organizaram o povoado de Santa Fé de Bogotá, o pároco ficou sendo o dos Welser.

53 (Habler 1903: 138). De acordo com esse autor, Castelhanos ignora as atividades protetoras de índios de Ampies. Juan de Castelhanos caracteriza os companheiros de Ampies como hábeis caçadores de índios.
} 
y de los religiosos que con vos iran los podais tomar y comprar, siendo verdadeiramente esclavos, pagandonos el quinto de los dichos esclavos".

Há notícias de que Ambrósio Ehinger chegando a Venezuela, imediatamente mandou apresar índios que foram vendidos em São Domingos; com o produto da venda comprou armas e cavalos para as expedições (Haebler 1903: 150). O certo é que logo após a fundação de Maracaibo, apresaram índios para vendê-los aos colonos e para fora da Venezuela. Há referências a diversos transportes de índios para São Domingos e também Coro recebeu índios apresados em Maracaibo. O governo espanhol terminou proibindo a escravização de índios, e a 5 de janeiro o governador Ambrósio Ehinger foi notificado dessa proibição. Os colonos porém não reconheceram essa proibição e consideraram-na altamente prejudicial. Ambrósio Ehinger, argumentando que as despesas dos Welser com a Venezuela eram 80.000 ducados e que o comércio com escravos índios praticamente era a única fonte de renda e que o apresamento era permitido pelo asiento, recebeu autorização real (10 de maio de 1531) que permitia a escravização, mas proibia a venda desses escravos para fora da Venezuela (Haebler 1903: 152). Também contra essa proibição os colonos protestaram. O governo espanhol ainda tomou outras medidas, assim quis evitar o abuso da "guerra justa", instituiu um protetor dos índios, que devia cuidar dos índios submetidos, e a 20 de fevereiro de 1534 fixou como e quem tem o direito de dirigir a uma tribo a exigência para que se submetesse. Ao governador e ao protetor cabia a decisão; esses podiam transmitir o direito de estudar o caso a duas pessoas do clero, resguardando-se, entretanto, a decisão final para o governador e o protetor. Só com a permissão de ambos é que os colonos podiam escravizar os índios e vendê-los, mas só dentro das fronteiras da colônia. Parece que essa proibição nunca foi obede-

\footnotetext{
${ }^{54}$ Apud Panhorst (1928: 194-7) Herrera (1726: 71) diz: “Que pudiesen tomar por Esclavos los Indios rebeldes, si avendo amonestados, no quisiesen obedecer, guardando en ello las Instruciones i Provisiones dadas para este caso; i que pudiesen comprar Esclavos de los Indios de la tierra, siendo lo verdaderamente, con intervencion de los Religiosos, i Oficiales Reales pagando de ellos el quarto al Rei".
} 
cida. O bispo Bastidas que é uma figura ambígua no que se refere a esse comércio de escravos indígenas, foi nomeado protetor dos índios, porém, diversas vezes aparece facilitando sua escravização e sua venda para São Domingos (Haebler 1903: 156). As dificuldades surgidas em Coro muitas vezes foram causadas por problemas com os índios escravizados. Não raro os índios se rebelavam, massacravam a população e fugiam, faltando por conseguinte braços para a lavoura. Hohermut resolveu o problema de falta de braços, exigindo que todos os índios dentro da área de colonização deviam trabalhar três dias por semana para os Welser. Hutten organizou sua grande expedição, prescindindo da colaboração dos indígenas e proibiu o recrutamanto dos mesmos como carregadores até além da boca de los llanos e Hacarigua. Parece que Hutten foi o único que tomou medidas para proteger os silvícolas ${ }^{55}$.

É difícil atinar com as verdadeiras proporções do apresamento na Venezuela, pois todos os dados visivelmente não correspondem à realidade. Bartolomeu de las Casas, o incansável defensor dos índios, faz fortes acusações contra os Welser. Esse religioso é responsável pela animosidade contra a tentativa alemã que caracteriza muitas crônicas e mesmo obras de história escritas mais recentemente. Diz las Casas:

\begin{abstract}
"Suas devastações [dos alemães] foram imensas, eles fizeram perecer quatro a cinco milhões de habitantes sobre uma extenção territorial de quatro ou cinco centos de léguas; de maneira que mesmo a lingua de tantas tribos e nações foi apenas conservada por alguns homens que se retiraram para as montanhas e as florestas ou que se esconderam em cavernas [... ]. Os alemães estavam sem um meio legítimo ou justificação, pois eles tinham sido recebidos como amigos deles, índios, no meio de festas e acumulados de presentes, mas eles aproveitaram tão
\end{abstract}

\footnotetext{
${ }^{55}$ Haebler (1903: 231). Não se sabe muito bem se na Venezuela dos Welser foi instituído o tipico sistema de repartimientos e encomiendas como vigorava no resto da América espanhola. Parece que houve ordens reais para se instituir esses sistemas, mas os colonos não apoiaram essas medidas. Navarro, por exemplo, como juiz e comissário real causou conflitos entre os colonos devido as suas idéias sobre encomiendas e repartimientos.
} 
bem a lição dos espanhóis, que foram ainda mais cruéis que eles, apesar de ser difícil sobrepujá-los" ${ }^{, 56}$.

Vê-se que Bartolomeu de las Casas exagerou. Como que um punhado de homens pode apresar ou matar quatro a cinco milhões de índios? Las Casas continua e dá a cifra dos que foram vendidos para fora das fronteiras da província dos Welser:

"O que há de incontestável, é que os alemães enviaram e fizeram vender mais que um milhão de escravos para Santa Marta, Jamaica, ilha de San Juan e São Domingos, onde está estabelecido o supremo tribunal da Audiência Real, cujos conselheiros não podiam ignorar o que se passava, pois esses países estavam dentro do limite da sua jurisdição, como no momento em que escrevo, em 1542, e que eles daí dependeram durante os 16 anos em que os barcos fizeram esse tráfico infame. Entretanto, longe de punir semelhantes crimes, eles os aprovavam, e os aprovavam também comprando índios para empregá-los em seus serviços como escravos levando a marca do rei”.

A cifra de um milhão de escravos índios transportados para outras terras não pode, de maneira nenhuma, corresponder à verdade. Haebler, baseando-se em carta de Rodrigo de Bastidas de 1538 sobre o pagamento do quinto devido ao rei de 1529 até 1538, calculou que o número de índios escravizados dentro da lei e que pagaram o quinto é de apenas 1005. O próprio Haebler acha que essa cifra é exageradamente pequena (1903: 158). O fato é que houve o apresamento sob conivência da coroa e esse comércio deve ter dado bons lucros para os Welser; a cifra de índios escravizados, entretanto, não pode ser calculada por causa da falta de dados nos quais se possa confiar.

O interessante é que os Welser não conseguiram impedir que escravagistas de fora fizessem incursões preadoras em seu território. Parece que a própria Audiência de São Domingos estava interessada em incursões desse tipo. Houve diversas proibições reais e se deu aos Welser amplos poderes para afastar os intrusos. A 17

\footnotetext{
${ }^{56}$ Prémier Mémoire, contenant la Relation des cruautés commises pa les Espagnols conquérans de l'Amérique; oueuvres de don Barthélemi de las Casas, vol. 1, p. 75, publicadas por J. A. Llorente.
} 
de fevereiro de 1537 uma proibição real foi dirigida especialmente contra os colonos de Santa Marta e os preadores de Cubagua, fixando a multa para cada incursão em 50.000 castellanos de ouro (Haebler 1903: 147). Mas as desordens causadas por essas expedições estranhas continuavam e essas incursões só terminaram na segunda metade do século XVI, quando a Venezuela já não pertencia mais aos Welser. Além do braço indígena, os colonos da Venezuela também lançaram mão dos escravos negros. Dos negros transportados pelos Welser para São Domingos, certamente uma parte se destinava à Venezuela.

$\mathrm{Na}$ Venezuela dos Welser, os colonos procuraram tirar proveitos da agricultura, da criação, e da coleta. Depois do abandono da política de explorações do interior por Tolosa, a agricultura e a criação se desenvolveram bastante. $O$ principal produto agrícola parece ter sido a cana de açúcar. Os rebanhos já eram relativamente grandes e tiveram certa importância durante o governo de Tolosa. Aliás, já a carta de doação da Venezuela estipulava que podiam levar livremente cavalos, éguas e gado das ilhas do mar das Antilhas para a Venezuela. Como as autoridades coloniais procurassem dificultar o transporte de gado, receberam nova concessão em 1535. A extração de madeira, principalmente a de tinturaria, tinha também relativa importância (Haebler 1903: 116 e 144). Outro produto procurado era um bálsamo extraído pelos índios da casca de uma árvore (Panhorst 1928: 134). Os colonos aprenderam dos índios o processo de extração, mas sua produção foi objeto de longos processos. Parece que esse bálsamo deu bons resultados, mas em 1534 os funcionários encarregados da fabricação foram despedidos. Nenhum historiador, entretanto, se preocupou em estudar mais profundamente tanto o sistema de plantação, como o da coleta ou da criação de gado, empregados na Venezuela. Só se preocuparam intensamente com as expedições e as pesquisas auríferas. O comércio, muito mais que as outras atividades, deu aos Welser grandes lucros. Vendiam mercadorias aos colonos, compravam deles o produto de seu trabalho. O imperador no asiento de 1528 lhes concedeu isenção de impostos para víveres transportados da Espanha para a Venezuela, somente tinham que pagar os impostos para os víveres destinados ao comércio. E mais ainda "que os ditos vizinhos que irão a dita terra na dita primeira viagem e 
depois nos oito anos logo seguintes, não paguem direitos de almoxarifado dos mantimentos e provisões que levarem para sua casa".

Os Welser ainda conseguiram outras vantagens. Em 1529 conseguiram um édito de Carlos V proibindo a intromissão de estranhos na colônia e os concessionários tinham amplos poderes de expulsar todos os indesejáveis. Esse édito, à primeira vista não tem nada a ver com o comércio, mas os Welser espalharam a notícia de que era proibido tocar em portos da Venezuela e de manter relações comerciais com os colonos. Asseguravam dessa maneira o monopólio do comércio para si. Com a reclamação das autoridades coloniais e dos colonos, a coroa teve que intervir (fevereiro de 1531) e libertar o comércio com a Venezuela, contanto que não prejudicasse os Welser (Haebler 1903: 111). No verão de 1532 apareceu em Coro o primeiro navio que não pertencia aos Welser. O reflorescimento do comércio de escravos índios trouxe muitos concorrentes aos Welser. Mais tarde conseguiram ainda algumas restrições quanto à intromissão de estranhos na colônia. Sem dúvida muito mais importante foi a concessão de agosto de 1530 que permite a viagem direta de Coro para Sevilha sem tocar em São Domingos e a Audiência de São Domingos recebeu ordens para não molestar os alemães. Essa concessão não se refere ao direito de viajar diretamente de Sevilha para a Venezuela, mas os Welser interpretaram a permissão de maneira a mais vantajosa para eles. O número de navios para Coro deve ter sido relativamente grande, mas não temos notícias precisas. Naturalmente comparado com o número de navios destinados ao tráfico negreiro, o de embarcações para Coro era diminuto. Parece que nos anos de 1532 e 1533 não chegaram muitos navios a Coro. Mas nos dois anos seguintes o movimento do porto foi intenso. Haebler (1903: 111-121) mostra que no inverno de 1534-1535 chegaram a Coro nada menos que 5 navios. Naturalmente a ligação de Coro com São Domingos, Santa Marta, Jamaica etc. foi bem mais ìntensa que a com a Europa. A 25 de janeiro de 1531 houve uma ordem que determinava que a direção da colônia tinha que pagar para todas as mercadorias e víveres importados para o comércio um imposto de 7,5\%. Os Welser, entretento, não aceitaram essa ordem, mostraram que o comércio era insignificante e que essa medida prejudicaria os colonos; pediram isenção de 
impostos para os artigos de primeira necessidade, e para instrumentos de mineração. A 10 de maio de 1531 conseguiram novas determinações e essas mercadorias podiam entrar livremente durante 5 anos, contanto que as mercadorias não excedessem o valor de 3.000 ducados anuais (Panhorst 1928: 161). Traziam da Espanha tudo que era necessário para a manutenção dos colonos, pois a colônia é claro, não oferecia no início todos os meios necessários para a subsistência ${ }^{57}$. Não temos muitas notícias sobre os produtos coloniais que eram transportados para a Europa. Levavam para a Espanha açúcar, pau brasil, drogas, especiarias, canafístula etc. O pau brasil, entretanto, era de péssima qualidade e não podia concorrer com o do Brasil. Os navios obrigatoriamente tinham que voltar a Sevilha para lá pagar 71/2\%. Naturalmente também os metais preciosos eram de certa importâcia, se bem que os Welser nunca tiveram a sorte de encontrar tanto quanto Cortez ou Pizarro.

Os Welser pediram que se lhes concedesse isenção de impostos e permissão para reexportar todas essas mercadorias para os outros países. Conseguiram a isenção de impostos mas precisavam limitar-se à Espanha e às suas colônias (4 de abril de 1531). Os resultados dessa concessão são ignorados; sabe-se apenas que o comércio com Santa Marta era bastante intenso, pois lá existia, segundo tudo indica, uma agência dos Welser (Haebler 1903: 126 e Panhorst 1928: 163).

Desde o início da colonização, os colonos se queixaram contra os Welser, dizendo que esses os exploravam na venda de artigos de primeira necessidade. Em 1536 os colonos se dirigiram diretamente ao Conselho das Índias, que, entretanto, enviou as queixas à Audiência de São Domingos. Os Welser se defenderam, mostrando que houve uma elevação geral de preços e que em outras partes do Novo Mundo os preços eram mais elevados. O problema das relações entre os Welser e os colonos era grande. Os Welser davam crédito aos colonos para que estes pudessem se preparar para as expedições. Muitos colonos abandonavam a Venezuela sem antes prestar contas aos

\footnotetext{
${ }^{57}$ Há notícias de que os Welser importavam ainda em 1538 grandes quantidades de farinha, carne salgada, óleo e vinagre.
} 
Welser. Assim, Ambrósio Ehinger foi obrigado a só fornecer crédito aos que se comprometeram a não sair da província sem permissão especial e antes de reconhecer suas dívidas. Finalmente, para maior segurança, estabeleceu-se um sistema de fiança; não se dava mais crédito a um colono isoladamente. Um grupo de colonos respondia pelas dívidas que um dos membros fizesse. Isso também era um meio para garantir o pagamento das dívidas de um colono que perecesse numa expedição, pois dessa maneira seus bens, antes de serem distribuídos pelos companheiros, eram aproveitados primeiro para amortizar sua dívida. Essas medidas naturalmente deram margem a queixas dos colonos. As dívidas dos colonos não eram pequenas, em 1533 os oficiales davam em seus relatórios uma cifra de 50.000 ducados e em 1546 a cifra tinha subido para 80.000. Em 1547, por exemplo, forneceram aos colonos mercadorias no valor de 120.000 pesos, dos quais apenas 20.000 foram pagos (Haebler 1903: 197, 217 e 382).

Apesar do fracasso geral da empresa dos Welser na Venezuela, parece que esses banqueiros de Carlos V obtiveram certo lucro. O comércio, a mineração e o tráfico de escravos indígenas devem ter dado margem a uma boa renda apesar de sempre se terem queixado de que o capital empatado não estava rendendo juros. Além disso, o asiento de 1528 estipulava ainda que $4 \%$ das rendas do rei tirando primeiro os gastos que a coroa tinha com a administração e com os salários dos funcionários, caberiam aos Welser. Haebler (1903: 360) cita um documento que o humanista Peutinger dirigiu a Bartolomeu Welser, segundo o qual a Venezuela estava dando lucros; não se tem, entretanto, notícias sobre o vulto desse lucro.

Para o período que vai de 1528 até dezembro de 1538, temos um balanço sobre os lucros da coroa. Esse balanço foi feito pelo bispo Bastidas. Trata-se do primeiro balanço realizado na Venezuela. As multas deram uma soma de apenas 153.448 maravedis (cerca de 400 ducados). O lucro do quinto sobre escravos índios também não foi grande, aproximadamente 1800 ducados, portanto um escravo índio valia cerca de 9 ducados, pois só de 1005 escravos tinha sido pago o quinto real ${ }^{58}$. Os

\footnotetext{
${ }^{58}$ Archivo General de Indias, 2 -2; 1/14. O número de escravos índios é por demais pequeno e não deve corresponder à realidade.
} 
impostos aduaneiros renderam somente 245.700 maravedis (cerca de 655 ducados). Quanto ao quinto de metais preciosos, Bastidas dá uma cifra de 17.814 pesos. O lucro total da coroa foi de 15.665 ducados. As cifras, entretanto, não são exatas. Haebler que estudou profundamente o documento, chegou à conclusão de que de maneira nenhuma se pode confiar nesses dados e tirar deles qualquer conclusão. Percebe-se, portanto, que não se pode chegar a conclusões nem quanto ao lucro dos Welser, nem quanto ao da coroa, devido à falta de documentação comprovante.

Haebler em sua magistral obra Die Ueberseeischen Unternehmungen der Welser und ihrer Gesellschafter (1903: 392-396), dividiu a história da colônia dos Welser na Venezuela em três períodos. Quando receberam a província queriam fazer da Venezuela um entreposto para seu comércio e um fornecedor de escravos indígenas. Pretendiam igualmente organizar plantações. Parece que obtiveram bons lucros com essas atividades, apesar de terem empatado grandes somas. A primeira fase, entretanto, foi efêmera, durou apenas de 1528 até 1534. A partir dessa data todos os colonos só se interessraram pela procura do Eldorado. Os Welser esperavam que o capital empatado rendesse juros não com as atividades comerciais e com a agricultura, mas com a descoberta de jazidas de metais preciosos. Todos os esforços foram despendidos nas expedições e a decadência da colonização se fêz sentir. Essa segunda fase vai até 1546. A última fase que vai até 13 de abril de 1556, quando os Welser perderam todos os direitos sobre a Venezuela, caracteriza-se não mais pelas expedições ou pelas atividades comerciais, mas pela luta, pelo direito que lhes havia sido outorgado em 1528. A província continuava nominalmente em poder dos Welser, mas esses nada mais lá empreenderam. Foram muitos os processos movidos por agentes reais contra os Welser. Continuamente a Audiência de São Domingos se intrometia em negócios da Venezuela; essa intromissão data da nomeação do bispo Bastidas para governador, por acasião da morte de Ambrósio Ehringer. Por vezes os Welser se cansaram dos processos, desinteressando-se em manter a colônia. Assim, por exemplo, de 1550 a fins de 1553 ou começo de 1554 não se preocuparam em lutar pelos seus interesses. Sua principal preocupação a partir de 1548 foi obter uma cópia de seus asientos para poderem pedir uma prorrogação para outra geração. $\mathrm{Na}$ 
realidade, queriam uma cópia de seus privilégios, pois isso significaria o reconhecimento dos mesmos. Além dos diferentes processos, havia ainda uma disputa entre os Welser e a coroa devido a nomeação de Villegas como governador, contra a qual o procurador real havia reclamado. A 21 de março de 1555 foram proclamadas as sentenças dos diferentes processos. Todas as sentenças foram favoráveis aos Welser: deviam receber a ratificação de seus privilégios, Villegas foi reconhecido governador em nome dos Welser. O procurador, entretanto, entrou com um recurso, e até a resolução do mesmo, os Welser nada puderam fazer. A 13 de abril de 1556, em Valadolid, foi publicada a sentença definitiva: os Welser perderam todos os direitos sobre a Venezuela, que passou para a coroa (Haebler 1903: 389). Todas as acusações aos Welser, entretanto, foram afastadas, percebe-se mesmo que tinham a intenção de justificar a atuação dos antigos banqueiros de Carlos V. Supõe-se que os Welser se conformaram com a sentença, pois só se tem notícias muito vagas sobre sua atitude em relação à perda dos direitos sobre uma região, onde, afinal de contas, tinham empatado grandes somas.

Quais as causas que explicam o fracasso dos Welser na Venezuela? Sem dúvida, a causa mais importante foi a hostilidade contínua e visível dos espanhóis com relação a todos os estrangeiros. Nunca se conformaram com o fato de Carlos V ter doado a alemães uma região que por direito lhes cabia. Desde o primeiro momento da colonização houve atritos entre os Welser na Venezuela e a Audiência de São Domingas. Devido às contínuas expedições para o interior, quase sempre o governo de Coro ficava abandonado, dando margem a graves desordens entre os colonos. Assim, as autoridades espanholas na América muitas vezes foram obrigadas a intervir. A sentença de 1556 nada mais é que uma consequência das idéias de Filipe II que retomou a velha política espanhola, apenas interrompida por um rei-imperador que pensava mais em termos europeus que castelhanos. Filipe II, já antes de seu pai se retirar para o convento, dirigia os negócios de Espanha e vinha exercendo uma forte pressão sobre o imperador por causa do monopólio de comércio que devia pertencer unicamente aos súditos da Espanha. Assim, os atritos com as autoridades, a diminuição do lucro, as constantes lutas com os índios e com os piratas causaram o 
desinteresse pelo empreendimento. Além disso, havia o problema da vitaliciedade da concessão dos privilégios e os Welser, tendo tantas dificuldades com a coroa, perceberam que era praticamente impossível conseguir uma prolongação dos mesmos. A própria situação geográfica da matriz dos Welser deve ter sido uma das causas do fracasso da colonização da Venezuela. De Augsburgo, no centro da Europa, não dispunham de facilidades para se comunicarem com a colônia, ainda mais que as guerras de religião isolaram quase completamente a cidade. Dificilmente os Welser de Augsburgo poderiam ter dirigido com eficácia a colonização da Venezuela.

Foi efêmera a participação dos alemães na colonização e exploração econômica da América. Apenas meio século. Mas enquanto ela durou mostrou um vigor extraordinário. Pelo que foi visto, sua atenção não se concentrou num só ponto: interessaram-se pelas mais diversas partes do Novo Mundo. E o Brasil? Participaram intensamente na vida econômica de Portugal, mantiveram feitorias nas ilhas portuguesas do Atlântico. Será que não se preocuparam com a terra de Santa Cruz? É interessante a inclusão de um item que se refere ao pau brasil e ao monopólio de Fernando de Noronha nos privilégios concedidos aos Welser em fevereiro de 1503:

\footnotetext{
"Item nos praz, e conçedemos que se us ditos mercadores comprarem em pequena ou grande quantidade Especiarias ou brasil ou outras quaes quer mercadorias trazidas da India ou de terras nouas proximamente achadas não seião obrigados por tal compra hagar siza nem outro direito ou tributo leuando as ditas mercadorias fora de nossos Reinos, e Senhorios... e pello semelhante pagarao outro tanto das mercadorias que comprarem das naos de fernão de noronha nosso Subdito durando seu contrato que por nos com elle he firmado das terras nouas o qual trato se acabara no anno de quinhentos, e sinquo...".
}

De certo houve alguma razão para se incluir isso no texto dos primeiros privilégios concedidos aos Welser e a outros alemães. Interessaram-se pelo comércio do pau brasil proveniente do Brasil? Na realidade não se sabe nada de concreto sobre as relações dos banqueiros alemães com o Brasil. Roberto Simonsen (1944: 147) afirma, sem 
entretanto precisar a fonte, que Pero Lopes de Sousa e Pero Lopes da Silveira se associaram "a flamengos e alemães para a inslalação de alguns engenhos"

Uma prova do interesse dos alemães para com o Brasil seria a famosa Newe Zeitung aus Pressilg-Land. Sobre esse documento já se tem discutido muito, mas sua importância é incontestável, sendo mesmo ressaltada pelos estudiosos da literatura alemã $^{60}$. A simples presença desse panfleto, do qual foram encontrados cerca de 10 exemplares impressos provenientes de 3 edições diferentes, mostra que os alemães se interessaram vivamente pelo Brasil nas primeiras décadas do século XVI.

Os alemães, que durante algum tempo se preocuparam tanto com os negócios coloniais, fracassaram inteiramente. Esse fracasso prova que apesar de tudo o sistema capitalista estava imaturo, pois sem o auxílio de um governo forte e bem organizado, a empresa particular dos alemães teria obtido sucesso somente se pudesse contar com um capitalismo plenamente desenvolvido. Não se deve esquecer que as desordens religiosas, além de isolar o sul da Alemanha do resto da Europa contribuiram também para abalar o poderio capitalista dos antigos banqueiros de Carlos V. Lançaram-se à empresa colonial e conseguiram afirmar-se na América espanhola durante o período em que eram apoiados pelo governo, mas quando o apoio de Carlos V deu lugar às hostilidades dos espanhóis, fracassaram. O declínio do poderio econômico dos banqueiros coincide com o abandono de todas suas atividades na América. Na segunda metade do século XVI não encontramos mais os alemães no comércio colonial da América e eles não ocupam mais o lugar de destaque na vida econômica da Europa.

\footnotetext{
${ }^{59}$ É possível que os alemães estivessem ligados às primeiras tentativas de cultura de cana no Brasil, pois é bem conhecida sua ligação com os Schetz do famoso engenho dos Erasmos de São Vicente. ${ }^{60}$ A maioria dos historiadores acredita que se trata de uma tradução para o alemão de um documento italiano. Haebler, encontrando um manuscrito no arquivo dos Fugger, conseguiu verificar que se trata de uma carta escrita na ilha da Madeira e enviada a um amigo do redator em Antuérpia. Se realmente for assim, o redator desse documento pode ser procurado na feitoria dos Welser naquela ilha. Os Fugger devem ter usado esse documento para se inteirarem das condições do Novo Mundo por ocasião de suas conversações sobre a concessão da costa do Chile (Haebler 1895).
} 


\section{Referências Bigliográficas}

ABREU, João Capistrano de. O Brasil no século XVI (s/d).

ALLGEMEINE DEUTSCHE BIOGRAPHIE. Leipzig, Verlag Duncker und Humblot, 1896.

ANTHERO, Adriano. A História Económica. Porto, 1921.

BABELON, Jean. Charles Quint. Paris, Societé d'Éditions françaises et internationales, 1947

BRANDI, Carlos. Carlos V. Vida y Fortuna de una personalidad y de un imperio mundial. Madrid, Editora Nacional, 1943.

CASSEL, Johann Philipp. Privilegia und Handlungsfreiheiten welche die Koenige von Portugal eheden den deutschen Kaufleuten zu Lissabon ertheilet haben. Bremen, 1771.

CONRAD, J. História de la Economia. Barcelona, 1950.

CLOUGH-COLE. Economic History of Europe. Boston, 1941.

DAMASCHKE, Adolf. Geschichte der Nationaloeconomie. Jena, Verlag Gustav Fisher, 1929

DENUCÉ, J. Priviléges accordés aux Flamands et Allemands. Archivo Histórico Portuguez, vol. VII.

DESLANDES, Venancio Augusto. Documento para a História da Typographia Porgueza nos séculos XVI e XVII. Lisboa, 1881.

EHRENBERG, Richard. Das Zeitalter der Fugger-Geldkapital und Creditverkehr im 16. Jahrhundert. Jena, Verlag von Gustav Fischer, 1896.

HAEBLER, Konrad. Die Ueberseeischen Unternehmungen der Welser un ihrer Geselllschafter. Leipzig, 1903.

HAEBLER, Konrad. Die Geschichte der Fugger'schen Handlung in Spanien. Weimar, Verlag Emil Felber, 1897.

Kolonial Unternehmungen der Fugger, Ehinger und Welser im 16. Jahrundert. Zeitschrift der Geselschaft fuer Erdkunde zu Berlin, Berlim, 1892, vol. 27. 
. Die "Neuwe Zeitung aus Presilgl-Land" im Fuerstlich Fugger'schen Archiv. Zeitschrift der Geselschaft fuer Erdkunde zu Berlin, Berlim, 1895, vol. 30.

HARING, Clarence H. Comercio y Navigación entre España y las Indias. México, Fondo de Cultura Economica, 1939.

The Spanish Empire in America. Nova York, Oxford U. Press, 1947.

HARISSE. Bibliotheka Americana Vetustissima. Nova York, 1866.

HERING, Ernesto. Los Fucar. México, Fondo de Cultura Economica, 1944.

HERRERA, Antonio de. Historia General de los Hechos de los Castellanos en las Islas y tierra Firme del Mar Oceano. Madrid, 1726.

HEYCK, E. Kaiser Maximilian I. Verlag Vehlhagen u. Klasig Bielefeld e Lepzig, 1989.

HUMBERT, Jules. Histoire de la Colombie et du Vénézuéla. Librairie F. Alcán, 1921.

HUEMMERICH, Franz. Die Erste Deutsche Handelsfahrt nach Indien 1505-1506. Verlag R. Oldemburg, Munique e Berlim, 1922.

KLARWILL, Victor. Ungedruckte Briefe an das Haus Fuger aus den Jahren, 15681605. Rikola, Verlag. Jena, Lepzig e Munique, 1923.

LAS CASAS, Bartolomeu de. Oeuvres. J.A. Llorent. Paris, 1822.

LAPEYRE, Henri. Simon Ruiz et les Asientos de Philippe II. Librairie A. Colin, 1953.

LEWIS, D.B.W. Charles-Quint-Empereur d'Occident. Payot, 1932.

LOHMANN VILLENA, Guillermo. Las Minas de Huancavélica en los siglos XVI e XVII. Publicação da "Escuela de Estudios Hispano-Americanos de Sevilla". Sevilha, 1949.

MEDINA, J. T. Coleccion de documentos inéditos para la Historia de Chile. Vol. 3. Santiago de Chile, 1889.

MERRIMAN, Roger Bigelow. Carlos V, el emperador y el imperio español en el viejo y nuevo mundo. Tradução de G. Sans Huélin. Espasa-Calpe. Argentina, 1940.

MOLLWO, Carl. Koelner Kaufleute im 16. Jahrhundert auf den Kanarischen Inseln (transcrição do texto do documento). Mittheilungen aus dem Stadt-archiv, vol. 11, cadernos XXVIII e XXXIX, Colônia, 1899. 
MOSES, Bernard. The establishment of Spanish Rule in America. G.P. Putnam's sons N. York e Londres, 1898.

OAKESHOTT, W.F. Commerce and Society. Clarendon Press. Oxford, 1936.

OVIEDO y VALDES, Gonzalo Fernandes de. Historia General y Natural de las Indias, Islas y Tierra-Firme del Mar Océano. Madrí, 1855.

PANHORST, Karl H. Deutschland und America. Verlag Ernst Reinhardt. Munique, 1928.

POELNITZ, Goetz Freiherr von. Jakob Fugger-Kaiser, Kirche und Kapital in der oberdeutschen Renaissance. J.C.B. Mohr. Tuebingen, 1949.

Propylaeen Weltgeschichte. Publicada sob a direção de Walter Goetz, IV volume. Propylaeen Verlag. Berlin, 1932.

REM, Lucas. Tagebuch aus den Jahren 1494-1541. Publicado por B. Greiff. Augsburgo, 1861.

RUGE, Sopfus. Copia der Newen Zeytung auss Presillg Landt. Jahresbericht des Vereins fuer Erdkunde zu Dresden, 1866-1867.

SANTA CRUZ, Alonso de. Cronica del Emperador Carlos V. Madrí, 1920.

SANUTO, Marino. Diarii. Publicado por N. Barozzi. Veneza, 1880.

SCHERER. Geschichte der deutschen Literatur.

SCHMIDEL, Ulrich. Abenteuer in Suedamerica 1535-1554. Publicado por Curt Cramer, 2a edição. Brockhaus. Leipzig, 1926.

SCHMIDT, Max Georg. Historia del Commercio Mundial. Tradução de M. Sanchez Sarto. Labor, 1927.

SCHUMACHER, Hermann A Bremen und die Portugiesischen Handels - Freibriefe der Deutschen. Bremisches Jahrbuch. Verlag C. E. Mueller, 1892.

SÉE, Henri. Origen y Evolucion del Capitalismo Moderno. Tradução de M. Garza. Fondo de Cultura Economica. México, 1939.

SIEVEKING, Heinrich. Historia de la Economia. $2^{\text {o }}$ vol. Labor, 1942. 
SIMONSEN, Roberto. História Econômica do Brasil. Companhia Editora Nacional, 1944.

SOARES DE SOUZA, Gabriel. Tratado descritivo da terra do Brasil. Anotações de Pirajá da Silva. Livraria Martins Editora.

SOMBART, W. Der moderne Kapitalismus. Verlag Duncker und Humblot. Munique e Leipzig, 1928.

SOMMER, F. Die Deutschen in Brasilien Manuscrito em poder do Instituto Hans Staden. São Paulo.

Copia der Newen Zeytung ausz Pressillg Landt. Serra Post Kalender. Ijui, 1953.

STRIEDER, J. Zur Genesis des Modernen Kapitalismus. $2^{\mathrm{a}}$ edição. Verlag Duncker und Humblot. Munique e Leipzig, 1935.

WEBER, Max. General Economic History. Georg Allen and Unvin Ltd. Londres. The Protestant Ethic and the spirit of Capitalism. Tradução de T. Parson. Charles Scibner's Sons. N. York. 